\title{
LA IGUALDAD POR RAZÓN DE FILIACIÓN Y LA SUCESIÓN HEREDITARIA
}

\author{
Discrimination of reason of parentage and \\ the succession causa mortis
}

\author{
CAMINO SANCIÑENA ASURMENDI \\ Universidad de Oviedo \\ camino@uniovi.es \\ CLARA GAGO SIMARRO \\ Universidad de Oviedo \\ gagoclara@uniovi.es
}

Cómo citar/Citation

Sanciñena Asurmendi, C. y Gago Simarro C. (2019).

La igualdad por razón de filiación y la sucesión hereditaria.

Derecho Privado y Constitución, 34, 139-195.

doi: https://doi.org/10.18042/cepc/dpc.34.04

(Recepción: 27/12/2018; aceptación tras revisión: 10/06/2019; publicación: 26/06/2019)

\section{Resumen}

El presente trabajo se inicia con la situación actual de diferencia de trato entre hijos legítimos, ilegítimos naturales e ilegítimos no naturales respecto a los derechos sucesorios legales, según la fecha de fallecimiento del causante, dado que la sucesión mortis causa se regula por la legislación que esté en vigor en el momento de la apertura de la sucesión. Analiza la jurisprudencia del Tribunal Supremo y la doctrina del Tribunal Constitucional sobre los criterios de temporalidad de la Constitución española y la protección de la seguridad jurídica. 
Seguidamente aborda la equiparación de los hijos a los efectos sucesorios, con independencia del momento de apertura de la sucesión, planteando varios argumentos jurídicos para la no discriminación por razón de filiación, como la posible inconstitucionalidad sobrevenida de algunos preceptos de la redacción originaria del Código Civil, la oposición al orden público español, o la eventual vulneración del Convenio Europeo de Derechos Humanos según la jurisprudencia del Tribunal Europeo de Derechos Humanos.

\section{Palabras clave}

Filiación matrimonial y no matrimonial; legítimas; derechos hereditarios; discriminación.

\section{Abstract}

This paper begins with the difference in treatment given to legitimate, natural illegitimate and non-natural illegitimate children regarding their inheritance rights depending on the date of death of the deceased, since the inheritance upon death is ruled by the law in force at that time. It analyses the Supreme Court and Constitutional Court case-law about the criteria of temporality of the Spanish Constitution and the protection of the legal security. Afterwards, it addresses the children's equality concerning their inheritance rights. In so doing, it offers several legal arguments against the filiation discrimination, like the possible unconstitutionality of some articles of the original Civil Code, the infringement of the public order, the indirect discrimination or the violation of the European Convention of Human Rights according to the European Court of Human Rights case-law.

\section{Keywords}

Marital filiation; non-marital filiation; compulsory share; inheritance rights; discrimination. 


\section{SUMARIO}

I. ESTADO DE LA CUESTIÓN: 1. La entrada en vigor de la Constitución como «fecha de corte». 2. Las sucesiones abiertas antes de la Constitución y la disposición transitoria octava. II. RAZONES PARA LA NO DISCRIMINACIÓN DE LOS HIJOS NO MATRIMONIALES: 1. La aplicación directa de la Constitución. 2. El argumento de la consumación o agotamiento de los efectos sucesorios. 3. El control de constitucionalidad y la disposición transitoria séptima. 4. La excepción de orden público. 5. La denominada discriminación indirecta. 6. El criterio del Tribunal Europeo de Derechos Humanos sobre la fijación de una «fecha de corte». BIBLIOGRAFíA. ANEXO. ÍNDICE DE SENTENCIAS Y RESOLUCIONES.

\section{ESTADO DE LA CUESTIÓN}

La Ley 11/1981, de 13 de mayo, equiparó a los hijos con independencia de su filiación a efectos sucesorios, señalando en la disposición transitoria octava que las sucesiones causadas antes de la fecha de su entrada en vigor se regularán por la legislación que estuviese en vigor en el momento de la apertura de la sucesión. En este sentido, el Tribunal Constitucional y el Tribunal Supremo resuelven las sucesiones abiertas con anterioridad a la Constitución, aplicando el Código Civil en su redacción originaria por remisión de la disposición transitoria octava, de manera que produce una disparidad en los derechos sucesorios entre hijos legítimos, ilegítimos naturales e ilegítimos no naturales ${ }^{1}$.

El Código Civil de 1889 otorgaba diferentes derechos sucesorios a los hijos dependiendo de su filiación ${ }^{2}$. Por un lado, se situaban los hijos legítimos, a los que la ley reservaba como legítima dos tercios del caudal hereditario (arts. 807 y 808) y llamaba en la sucesión intestada con carácter preferente (art. 931). En segundo lugar, los hijos naturales legalmente reconocidos o legitimados,

1 Sirva de muestra la STC 105/2017, de 18 de septiembre, y la STS de 29 de abril de 2015.

2 Para la evolución histórica del régimen jurídico de las distintas categorías de hijos y sus derechos sucesorios, véanse Alemany Verdaguer (1974) y Polo Arévalo (2011). 
quienes tenían derecho a la legítima en la herencia de sus progenitores de cuantía variable en función de que concurrieran con hijos o descendientes legítimos, con ascendientes legítimos, con el cónyuge viudo, o concurrieran solos, pero siempre inferior a la de los hijos legítimos (arts. 840 a 844). En la sucesión intestada, sucedían al causante en línea recta descendente en la legítima si concurrían con descendientes y ascendientes legítimos (arts. 940 a 942), y a falta de estos sucedían en toda la herencia (art. 939); pero no heredaban a los hijos ni a los parientes del progenitor (art. 943). Por último, los hijos ilegítimos no naturales, a los que se equiparaban los hijos naturales no reconocidos ni legitimados, carecían de derecho a la legítima y de derechos sucesorios $a b$ intestato, solo se les reconocía un derecho a alimentos (arts. 139 y 845)

El principio constitucional de igualdad ante la ley de todos los españoles (art. $14 \mathrm{CE}$ ), y en concreto, de todos los hijos con independencia de su filiación (art. 39.2 CE), fue incorporado al Código Civil en materia de filiación mediante la Ley 11/1981, de 13 de mayo, cuyo art. 108 establece que las distintas filiaciones surten los mismos efectos, equiparando a los hijos y otorgándoles los mismos derechos sucesorios. Así, el art. 807 del Código Civil atribuye la legítima de dos terceras partes de la herencia a favor de los hijos o descendientes del causante, sin atender a su filiación matrimonial o no matrimonial, y el art. 931 les llama como sucesores intestados en primer lugar.

La Ley 11/1981, de 13 de mayo, previó diversas disposiciones de derecho transitorio ${ }^{4}$. En lo que interesa, cabe destacar la disposición transitoria primera, que señala que los efectos de la filiación se regirán por la ley

3 La Ley de 24 de abril de 1958 de reforma del Código Civil modificó algunos artículos de la versión originaria del Código Civil que afectan al presente trabajo, como los arts. $807,809,814,834$ a 839 y 841 . Y en menor medida los arts. 173 a $180,772,855$, 952 y 953 .

Cuando esta reforma haya afectado al contenido de un artículo en el sentido en el que se utiliza en el presente trabajo se señalará oportunamente. En caso contrario, la referencia que a lo largo del trabajo se haga a la redacción originaria del Código Civil se puede aplicar también a la versión de 1958.

Curiosamente, la Ley de 1958 redujo la cuantía de la legítima de los hijos naturales reconocidos cuando concurrían con ascendientes legítimos, que pasó de la mitad de la herencia a una cuarta parte (art. 841).

4 Las disposiciones transitorias tercera, cuarta, quinta y sexta se refieren al reconocimiento de los hijos ilegítimos no naturales y a las acciones de filiación; la disposición transitoria segunda equipara a los hijos legitimados por concesión con los hijos no matrimoniales respecto a los derechos sucesorios y de alimentos.

Véanse sobre el derecho transitorio De la Cámara (1984: 960-988) y Miquel González (1984: 1992-2001). 
posconstitucional «con independencia de la fecha de nacimiento y del momento en que la filiación haya quedado legalmente determinada». La disposición transitoria séptima según la cual "las acciones de filiación se regirán exclusivamente por la legislación anterior, cuando el progenitor cuestionado o el hijo hubiere fallecido al entrar en vigor la presente Ley». Y paralela a esta disposición, la numerada como octava dispone que «las sucesiones abiertas antes de entrar en vigor esta Ley se regirán por la legislación anterior y las abiertas después por la nueva legislación ${ }^{5}$.

Según estas disposiciones de derecho transitorio, en el caso de que el progenitor hubiera fallecido con anterioridad a la entrada en vigor de la Ley 11/1981, es decir, antes del 8 de junio de 1981, tanto la acción de reclamación de la filiación como la sucesión se regularían por las normas originarias del Código Civil, más estrictas en cuanto a la legitimación y plazos para la reclamación de la filiación y más restrictivas en cuanto a los derechos hereditarios de los hijos ilegítimos y naturales.

\section{LA ENTRADA EN VIGOR DE LA CONSTITUCIÓN COMO «FECHA DE CORTE»}

Desde el principio, se cuestionó una interpretación literal o estricta de la disposición transitoria octava según la cual la equiparación de los hijos a efectos sucesorios se produciría en las sucesiones causadas una vez que hubiera entrado en vigor la Ley 11/1981, de 13 de mayo. Se defendía que la Constitución española era de aplicación directa e inmediata, por lo que se debería

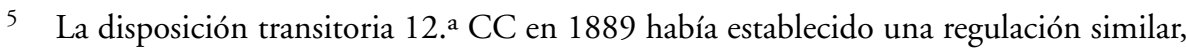
aunque había introducido el matiz de respetar cuando fuera posible el último testamento, aunque se hubiese realizado antes de la entrada en vigor del Código Civil. En este sentido, la STS de 16 de enero de 1895 resuelve la testamentaría de un causante fallecido en 1891 en estado de soltero, con testamento realizado en 1885, en el que instituía herederos a sus hermanos, y otorgaba un legado a favor de una hija natural, reconocida el 1 de enero de 1889. La madre de la hija natural demanda, de conformidad con el Código Civil, que se declare nula la institución de herederos y se nombre única heredera a la hija natural. El juzgado desestima la demanda, la audiencia la estima y el Tribunal Supremo casa la sentencia de apelación. La sentencia aplica los preceptos del Código Civil que, «innovando en esta materia la antigua legislación, incluye en el art. $807 \mathrm{CC}$ entre los herederos forzosos á los hijos naturales legalmente reconocidos»; pero en atención a las disposiciones testamentarias, considera que el legado concedido a la hija natural cubre con amplitud el tercio de legítima que le corresponde por ser hija natural ex art. $842 \mathrm{CC}$, conservando la institución de herederos. 
adelantar la fecha de equiparación de los hijos a efectos sucesorios a la fecha de entrada en vigor de la Carta Magna, el 29 de diciembre de 1978. De esta manera se evitaría que las sucesiones abiertas entre la entrada en vigor de la Constitución y de la Ley 11/1981 quedaran sometidas a la normativa originaria del Código Civil, basada en el trato desigual entre hijos legítimos e ilegítimos ${ }^{6}$.

Con esta finalidad, la disposición transitoria octava fue objeto de una cuestión de inconstitucionalidad, planteada por el Juzgado de Primera Instancia de Mieres al conocer la sucesión hereditaria de dos causantes, marido y mujer, en la que el actor, hijo natural de un hijo legítimo premuerto, demandaba la nulidad de la institución de herederos y de los testamentos otorgados por los causantes, el abuelo y la abuela, y que se le declarase heredero en iguales condiciones a los otros hijos y descendientes legítimos. El supuesto resulta muy interesante por las fechas de apertura de las dos sucesiones, pues la abuela había fallecido en noviembre de 1978 y el abuelo, el 2 de octubre de 1980.

La Sentencia del Pleno del Tribunal Constitucional 155/1987, de 14 de octubre, salva en primer lugar el hecho de que una disposición transitoria de remisión al conjunto de una legislación no es susceptible de ser declarada inconstitucional, y expone que se hubiera debido señalar preceptos sustantivos concretos. La Sentencia reitera que los órganos de la jurisdicción ordinaria pueden realizar el control sobre las leyes preconstitucionales; considera que la disposición transitoria octava debe ser interpretada en su alcance temporal, pues el defecto que a la misma cabe achacar en virtud de su interpretación literal es, a su vez, un defecto solo predicable respecto de determinadas aplicaciones de la norma cuestionada (las que hubieran de producirse con posterioridad a 29 de diciembre de 1978), no de todas ellas. Finalmente concluye que la disposición transitoria octava de la Ley 11/1981, de 13 de mayo, no puede ser anulada, pues su ámbito de aplicación excede al de las normas sobre los derechos sucesorios por razón de filiación, además de que «no se remite de modo inequívoco a una redacción determinada de la legislación sucesoria, sino, de modo genérico, a la legislación anterior, expresión que sólo puede entenderse referida a la legislación vigente y que, por tanto, no excluye, sino que incluye, los cambios que en el contenido del Código civil produjo la entrada en vigor

6 A este respecto, De la Cámara Álvarez (1984: 986) señalaba «la clara discriminación según que la filiación fuese matrimonial o no matrimonial. Consiguientemente, cuando la apertura de la sucesión haya tenido lugar antes de entrar en vigor la nueva legislación, la discriminación subsiste». Y concluía que el Tribunal Constitucional «tendrá que declarar la inconstitucionalidad de la disposición transitoria octava». 
de la Constitución, cambios que, como es claro, está facultado para apreciar por sí el Juez ordinario ${ }^{7}$.

En efecto, la disposición transitoria octava no puede ser declarada inconstitucional, pues carece de contenido sustantivo al ser una norma de remisión $^{8}$. El Tribunal Constitucional en la Sentencia 155/1987 hubiera podido declarar inconstitucionales los arts. 139, 807-808, 840 a 847, 931 y 939-945 de la redacción originaria del Código Civil en cuanto establecen un trato diferente en los derechos sucesorios de los hijos dependiendo del carácter de su filiación, pero como la propia sentencia se lamenta, únicamente se había cuestionado la inconstitucionalidad de la disposición transitoria octava y no la de determinados preceptos del Código Civil. Por otra parte, la disposición transitoria octava tampoco puede ser anulada, puesto que las sucesiones causadas antes de la entrada en vigor de la Ley de 13 de mayo de 1981 se rigen por el Código Civil vigente en el momento de la apertura de la sucesión, sin perjuicio de su adaptación a los principios constitucionales.

La consecuencia de esta sentencia ha sido la fijación de la entrada en vigor de la Constitución española, el 29 de diciembre de 1978, como fecha de corte para la aplicación de la igualdad ante la ley por razón de filiación en los derechos sucesorios. De manera que en las sucesiones causadas en el período de tiempo comprendido entre la entrada en vigor de la Constitución y de la Ley 11/1981, de 13 de mayo, el Tribunal Supremo aplica directamente el principio de igualdad y no discriminación por razón de nacimiento y filiación consagrado en el art. 14 de la Constitución, equiparando a los hijos y concediéndoles los mismos derechos sucesorios en la herencia de sus padres y demás

7 Con anterioridad, Miquel González (1984: 1993; 1986: 3438-3440) ya había manifestado que legislación anterior debería ser legislación en vigor y no legislación derogada, puesto que la legislación anterior no podía ser el Código Civil en su versión originaria derogado en sus normas discriminatorias por la Constitución, sino ese mismo Código en lo modificado por la propia Constitución.

En el mismo sentido, De Pablo Contreras (1987: 708) declaraba que «la legislación anterior a la que se remite la disposición transitoria octava no podía ser otra que el Código civil en su redacción entonces vigente con las modificaciones que la Constitución hubiese introducido en el mismo, en cuanto norma de aplicación inmediata y directa».

8 La disposición transitoria octava de la Ley 11/1981 no reúne los requisitos establecidos en el art. 35 de la Ley Orgánica del Tribunal Constitucional (LOTC) para ser objeto de una "cuestión de inconstitucionalidad» planteada de oficio o a instancia de parte por un juez o tribunal, dado que el órgano judicial sólo puede plantear la «cuestión de inconstitucionalidad» sobre una norma con rango de ley aplicable al caso y de cuya validez dependa el fallo. 
parientes; en todo lo demás esas sucesiones se rigen por el Código Civil en su redacción anterior a $1981^{9}$.

Una buenísima muestra de ello es la Sentencia del Tribunal Supremo que culminó el procedimiento origen de la Sentencia del Tribunal Constitucional 155/1987, de 14 de octubre, que lleva fecha de 26 de diciembre de 1990. El actor, hijo natural de un hijo premuerto, demanda sus derechos sucesorios en las herencias de sus abuelos paternos, fallecidos con dos años de diferencia, la abuela en noviembre de 1978 y el abuelo en octubre de 1980. El actor presenta demanda solicitando la nulidad de la institución de herederos por preterición no intencional y reclamando sus derechos sucesorios por derecho de representación. La sentencia de primera instancia, con base en las fechas de fallecimiento de los causantes, reconoce al actor derechos en la herencia del abuelo al equiparase las filiaciones por aplicación de la Constitución, y le niega todo derecho en la herencia de la abuela, aplicando el Código civil en su redacción originaria, dado que el hijo natural no genera vinculación con los parientes del padre (art. $943 \mathrm{Cc}$ ). El actor recurre en apelación y casación, que confirman la sentencia de la instancia.

Esta doctrina ha sido seguida por la Sentencia de 17 de marzo de 1995 que resuelve una reclamación de filiación no matrimonial y de derechos sucesorios. La actora reclama la filiación paterna no matrimonial respecto del causante fallecido el 26 de marzo de 1981, con impugnación de la filiación matrimonial que tenía reconocida, y la nulidad de la institución de herederos por preterición y, en su defecto, que se le reconozcan los dos tercios de legítima como única heredera forzosa. De conformidad con ello, el Tribunal Supremo determina que «la omisión de la actora en el testamento de su progenitor produce los efectos de la preterición, en cuanto se priva a la hija de manera tácita de los derechos legitimarios que le corresponden en la herencia de su padre». A renglón seguido concluye que «ha de procederse respecto de la herencia, según las reglas de la sucesión intestada», aplicando los art. 813, 814 y 834 del Código Civil en la versión originaria modificada por la Ley de 24 de abril de 1958, y adaptados al principio de igualdad por razón de nacimiento que impone la Constitución ${ }^{10}$.

9 Femenía López (2008: 145) señala que «la adaptación de las sucesiones abiertas entre la entrada en vigor de la Constitución y la Ley de 13 de mayo de 1981 a las normas y principios constitucionales no es consecuencia de la retroactividad de esta última sino de la eficacia directa de la Constitución en materia de derechos fundamentales, sin necesidad de desarrollo legislativo previo».

10 Espejo Lerdo de Tejada (I997: 408-409) sostiene que la hija solo tenía derecho a la legítima, y no a toda la herencia por la apertura de la sucesión intestada, pero lo fundamenta en aplicación de la disposición transitoria duodécima CC. 
Sin embargo, en algunas sentencias el Tribunal Supremo aplica preceptos del Código Civil en su redacción de 1981 a sucesiones abiertas con anterioridad a la entrada en vigor de la Ley 11/1981, como queda patente en la aplicación del art. 814 sobre la preterición. Así, resulta llamativo que la Sentencia de 13 de julio de 1985 otorga derechos sucesorios a la hija natural legalmente reconocida, aplicando el art. 814 del Código Civil en su redacción de 1981, casando la sentencia del juzgado de septiembre de 1980, que evidentemente había aplicado el art. 814 en su redacción de 1958. En el supuesto de hecho, el causante en testamento de 1971 había instituido heredera a su esposa, y había legado a su hija natural reconocida en 1951 lo que por legítima le correspondía. En un testamento posterior de 1976 instituye heredera universal a su esposa, sin mencionar a la hija natural. Esta solicita que se le considere preterida, se anule la institución de heredera y se le declare única heredera $a b$ intestato. El juzgado y la audiencia estiman la demanda. El Tribunal Supremo casa la sentencia, declara válido el segundo testamento y falla la preterición intencional atribuyendo a la hija natural la legítima estricta y protegiendo la institución de heredero a favor del cónyuge, de acuerdo con el art. 814 del Código Civil en su redacción de 1981, en vez de anular la institución de herederos y nombrar a la hija única heredera ab intestato, como hubiera correspondido según la redacción del citado precepto anterior a $1981^{11}$.

Igualmente, la Sentencia de 10 de febrero de 1986 aplica el art. 814 del Código Civil en su redacción de 1981 a una sucesión hereditaria causada en 1979. El causante había fallecido el 31 de enero de 1979, dejando tres hijos legítimos de su primer matrimonio contraído en 1934, y un hijo ilegítimo nacido en el año 1957 de una relación extramatrimonial. El causante había otorgado testamento abierto el 5 de octubre de 1977 en el que instituía herederos a sus tres hijos matrimoniales, sin hacer referencia alguna a su cuarto hijo, quien demanda la preterición y obtiene sus derechos legitimarios. Curiosamente el causante había otorgado el testamento después de haber quedado viudo y haber contraído ulterior matrimonio con la madre de su hijo ilegítimo en 1973. El Tribunal Supremo casa la sentencia de la audiencia y confirma la de primera instancia, que aplicaba el art. 814 del Código Civil en su redacción de 1981, reduciendo la institución de heredero en la cuantía necesaria para cubrir la legítima del descendiente preterido, y no anulando la institución de

11 Por este motivo, Rivero Hernández (1995: 268) y Miquel González (1985: 2888) critican la solución jurisprudencial. 
herederos, tal y como disponía el art. 814 del Código Civil en su redacción de 1889 y de $1958^{12}$.

\section{LAS SUCESIONES ABIERTAS ANTES DE LA CONSTITUCIÓN Y LA DISPOSICIÓN TRANSITORIA OCTAVA}

Las sucesiones causadas antes de la entrada en vigor de la Constitución española, al haber fallecido el causante con anterioridad al 29 de diciembre de 1978, se rigen por el Código Civil en su redacción originaria, de acuerdo con la remisión de la disposición transitoria octava de la Ley 11/1981, de 13 de mayo, a la legislación anterior, pero sin adaptarlo a los principios constitucionales y, por lo tanto, manteniendo una diferencia de trato entre los hijos legítimos, naturales e ilegítimos en la sucesión de sus progenitores y parientes.

La fecha de corte de la entrada en vigor de la Constitución española respecto al momento en que se causa la sucesión para la aplicación del principio de igualdad por razón de nacimiento a los derechos sucesorios es aplicada por el Tribunal Supremo también como fecha de corte para la no aplicación de una equiparación en el trato de los hijos según su filiación en las sucesiones causadas con anterioridad a esa fecha de corte.

En efecto, el Tribunal Supremo de manera constante y uniforme niega todo derecho sucesorio a los hijos ilegítimos y a los naturales no reconocidos, y reduce la cuantía de los derechos hereditarios a los hijos naturales reconocidos, sin aplicar el principio constitucional de igualdad y no discriminación por razón de nacimiento.

La argumentación en la que se basa el Tribunal Supremo en sus pronunciamientos se puede resumir en que la Constitución española no se aplica retroactivamente a situaciones que surgieron antes de su entrada en vigor, que

12 La doctrina ha vuelto a criticar la «aplicación retroactiva» del art. 814 CC en su versión de 1981. Así, Miquel González (1986; 3442) afirma que «en este asunto el Tribunal Supremo debía haber anulado la institución de heredero y haber reconocido al hijo extramatrimonial su cuota intestada, sin perjuicio de las mandas y legados que no fueran inoficiosos. Por el contrario, le ha reconocido tan sólo la legítima». Asimismo, De Pablo Contreras (1987: 712) señala que «el Tribunal Supremo, ante la evidencia de ser intencional la preterición del hijo no matrimonial, procedió a solventar el defecto señalado por la doctrina científica en el derogado artículo 814 , aplicando retroactivamente, con infracción de la disposición transitoria octava de la Ley de 13 de mayo de 1981, tal precepto en la redacción recibida por esta última Ley. Sin dudar de la justicia intrínseca de tal solución, no cabe sino constatar su incorrección formal». Rivero Hernández (1995: 267) sostiene que debió reconocerse al hijo extramatrimonial su cuota intestada. 
el texto de la Constitución no proclama una «retroactividad absoluta», que quebrantaría el principio de seguridad jurídica que también es un valor constitucional, y se podría producir una verdadera revolución jurídica respecto a situaciones ya superadas, creando el problema de los límites de tal retroactividad destructora de situaciones consolidadas ${ }^{13}$.

El Tribunal Constitucional ha ratificado la doctrina del Tribunal Supremo en la única sentencia recaída sobre este tema (STC 105/2017), y en el Auto 347/1988, de 16 de marzo, que en un único fundamento declara:

[...] la aplicación de las exigencias derivadas del derecho de igualdad en la filiación, que reconoce el art. $14 \mathrm{CE}$, supondría dotar a la norma constitucional de una eficacia retroactiva en grado máximo que no puede ser acogida, conforme a reiterada doctrina de este Tribunal, ya que afectaría, no sólo a relaciones jurídicas creadas al amparo de normas procedentes, sino a un fenómeno sucesorio que agotó totalmente sus efectos con anterioridad a la promulgación de la Constitución, y al que nada añade la acción hereditaria que se ejercita cuando ya ésta estaba vigente ${ }^{14}$.

Merece la pena exponer en un rápido recorrido, por orden cronológico, los supuestos de hecho y fallos de las resoluciones jurisprudenciales recaídas, dado que comparten los argumentos jurídicos. Esta exposición se inicia con

13 Las SSTS de 10 de noviembre de 1987, de 3 de febrero de 1990, de 8 de noviembre de 1991 y de 17 de marzo de 2005 aseveran que «la Constitución Española no se aplica retroactivamente a situaciones que surgieron antes de su entrada en vigor, pues en caso contrario se estaría quebrantando el principio de seguridad jurídica». Las SSTS de 10 de noviembre de 1987 y de 17 de marzo de 2005 continúan afirmando que «el principio de seguridad jurídica que también es un valor constitucional, y se podría producir una verdadera revolución jurídica respecto a situaciones ya superadas, creando el problema de los límites de tal retroactividad destructora de situaciones consolidadas».

14 La generalidad de los autores comparte la doctrina del TC y del TS en pro del principio de seguridad jurídica y de la aplicación de aquellas normas del Código Civil que conceden derechos diferentes a los hijos en razón de su filiación. Así, recientemente, Espejo Lerdo de Tejada (2018: 435) señala que «aplicar hoy unas normas que establezcan efectos discriminatorios resulta llamativo, pero parece que la seguridad jurídica obliga a ello, pues la CE no quiso ser retroactiva; y el criterio legal de derecho transitorio dispone que la sucesión se rige por las normas vigentes en el momento de la apertura de la misma (DT 12a CC y DT 8 Ley 11/1981)». En este mismo sentido, véanse Barber Cárcamo (2013: 53), Cobas Cobiella (2008: 431-442), Femenía López (2008: 131-167), Hornero Méndez (2016: 319-333), Martínez-Calcerrada y Gómez (2007: 1-3), Salas Carceller (2007: 467-472), Miquel González (1984), Seisdedos Muiño (2008; 89-102) y Viteri Zubia (2017: 15-31). 
los pronunciamientos del Tribunal Supremo y acaba con la más reciente Sentencia del Tribunal Constitucional 105/2017, de 18 de septiembre.

La Sentencia de 10 de noviembre de 1987 resuelve la sucesión de un causante fallecido el 23 de abril de 1972. En un primer testamento ológrafo de 1956, instituía heredera universal a una hija ilegítima y en un segundo testamento abierto de 1965 nombraba heredero universal, junto con la anterior, a otro hijo no matrimonial, ambos hermanos de doble vínculo. Finalmente, ocho horas antes de su fallecimiento, otorga testamento abierto, manifestando carecer de descendientes y ascendientes y nombrando heredera universal a su esposa. Los hijos extramatrimoniales del causante solicitan la nulidad del testamento por falta de capacidad y, subsidiariamente, la nulidad de la institución de herederos por preterición. Las sentencias de instancia y el Tribunal Supremo declaran la validez del testamento, por entender que el testador era capaz al tiempo de su otorgamiento, y que no había mediado fraude en la obtención de su última voluntad. Además, sostienen la validez de la institución de herederos por estimar que los hijos ilegítimos no naturales del causante no eran herederos forzosos al tiempo del fallecimiento de este, al aplicar la disposición transitoria octava de la Ley 11/1981 y la regulación originaria del Código Civil. Recurrida en amparo ante el Tribunal Constitucional, el Auto 347/1988, de 16 de marzo, citado, inadmite el recurso al no observar una discriminación por razón de nacimiento o filiación.

Dos supuestos similares, en los que se instituye heredero ab intestato al Estado, concurriendo con nieta y sobrina no matrimoniales, se resuelven por las sentencias de 13 de febrero de 1990 y de 8 de noviembre de 1991, respectivamente. La primera concede la herencia al Estado en vez de a la actora, hija natural reconocida de un hijo legítimo de la causante fallecida en el año 1969. El Estado había sido declarado heredero ab intestato en un procedimiento anterior. El Tribunal Supremo niega derechos hereditarios a la actora ex art. 943 del Código Civil (redacción originaria), atendiendo a la fecha de fallecimiento de la causante, anterior a la entrada en vigor de la Constitución. La Sentencia de 8 de noviembre de 1991 confirma la declaración del Estado como heredero ab intestato en la sucesión de la causante fallecida el 2 de julio de 1978, con preferencia a una hermana de vínculo sencillo, hija ilegítima de su padre, también por aplicación del art. 943 del Código Civil (redacción originaria), que negaba a los hijos naturales reconocidos el derecho a heredar a los parientes legítimos de su padre.

La Sentencia de 28 de julio de 1995 estima la declaración de filiación paterna no matrimonial, pero niega a los cuatro demandantes hijos no matrimoniales los derechos sucesorios dado que el causante había fallecido el 4 de febrero de 1978, con anterioridad a la Constitución. El causante había otorgado testamento en julio de 1976 en el que instituía heredera universal 
a otra hija extramatrimonial reconocida. Los actores solicitan, por un lado, la declaración de filiación extramatrimonial y, por otro, la nulidad del testamento por preterición y la apertura de la sucesión intestada. Las sentencias de instancia declaran la filiación extramatrimonial, con todas las consecuencias legales, reconociendo a los demandantes derecho a la parte proporcional de legítima estricta ${ }^{15}$. El Tribunal Supremo revoca parcialmente la sentencia de apelación, mantiene el pronunciamiento en cuanto a la declaración de filiación de los hijos naturales, pero no les reconoce ningún derecho sucesorio, dado que carecían de la condición de hijos naturales reconocidos.

La Sentencia de 6 de noviembre de 1998 resuelve el litigio sobre la herencia de un causante, fallecido intestado el 1 de marzo de 1949. El causante de soltero había tenido un hijo natural reconocido e inscrito en Cuba en 1921. En 1992, el hijo natural solicita la declaración de heredero intestado contra los cuatro hijos matrimoniales. La Sentencia de la Audiencia Provincial de Lugo de 27 de abril de 1994 estimó la demanda y nombró al hijo natural (único) heredero ab intestato. El Tribunal Supremo estimó la incongruencia solicitada por los hijos matrimoniales, declaró que los cinco hijos son herederos legales cada uno con su cuota específica (art. 942 CC en su redacción originaria), y desestimó la prescripción, aunque la demanda se había interpuesto más de cuarenta años después de la muerte del causante, pues no se había solicitado declaración de herederos, no había habido partición ni prescripción adquisitiva de los bienes hereditarios.

La Sentencia de 17 de marzo de 2005 resuelve la reclamación por el actor de la filiación paterna y los derechos sucesorios del causante fallecido el 21 de marzo de 1976. El juzgado de primera instancia había estimado ambos pedimentos. La sentencia de la audiencia confirma la declaración de la filiación no matrimonial, y revoca parcialmente la sentencia para negar al actor derechos hereditarios. Se basa fundamentalmente en que la herencia estaba agotada desde la apertura de la sucesión en 1976. Considera aplicable la disposición transitoria octava de la Ley 11/1981 y los preceptos de la redacción originaria del Código Civil, por lo que no le reconoce derechos sucesorios. El Tribunal Supremo declara no haber lugar al recurso, confirmando la aplicación de la

15 Las sentencias de instancia habían estimado la preterición de los cuatro hijos extramatrimoniales, pero habían aplicado el art. 814 CC en su redacción de 1981, al concederles únicamente lo que por legítima les corresponde (preterición intencional); en vez de aplicar este art. 814 CC en su redacción del año 1958, que determinaba la anulación de la institución de heredero y la apertura de la sucesión intestada, por lo que de reconocérseles derechos sucesorios, deberían haber heredado los cinco hijos extramatrimoniales del causante. 
disposición transitoria octava y negando los derechos sucesorios al hijo que, aunque natural, no había sido reconocido.

Especialmente sensible resulta el supuesto de hecho de la Sentencia de 31 de julio de 2007. El causante había contraído matrimonio en 1927, del que nacieron cuatro hijos matrimoniales. En 1942, los cónyuges se separaron mediante sentencia canónica de separación personal, y el causante inició una convivencia hasta su muerte en 1976 con otra mujer con la que tuvo siete hijos, y con la que contrajo matrimonio canónico quince días antes de morir, nada más quedarse viudo. Los cuatro hijos matrimoniales aceptaron la herencia en 1979. Los siete hijos ilegítimos obtuvieron declaración de herederos por acta de notoriedad en 1994. Contra la referida acta de notoriedad, los cuatro hijos matrimoniales presentaron demanda de nulidad, solicitando ser declarados los únicos herederos atendiendo a la fecha de fallecimiento de su padre. Las sentencias de instancia desestimaron la demanda interpuesta por los hijos matrimoniales contra el acta de notoriedad, de manera que reconocieron iguales derechos sucesorios a los once hijos; consideraron injusto y desproporcionado aplicar la normativa del Código Civil (redacción originaria) en el tiempo de vigencia de la Constitución española y además contrario a la realidad social del momento, y concluyeron que la redacción originaria del Código Civil, en cuanto discriminatoria por razón de filiación, no era aplicable a un supuesto litigioso iniciado con posterioridad a la Constitución. Por el contrario, el Tribunal Supremo casó la sentencia de apelación, entendió de aplicación la disposición transitoria octava y por remisión el artículo 139 del Código civil (redacción originaria) que negaba derechos sucesorios a los hijos ilegítimos no naturales, por lo que declaró únicos herederos a los cuatro hijos matrimoniales del causante ${ }^{16}$. Esta sentencia tuvo un voto particular disidente con el fallo y favorable a la aplicación del principio de igualdad y no discriminación por razón de nacimiento del magistrado O’Callaghan Muñoz, quien considera que «después de la Constitución, los tribunales no pueden aplicar una norma frontalmente contraria a la Constitución, norma injusta y obsoleta que atenta a los derechos humanos propios de un Estado de Derecho».

16 Véanse los comentarios de esta sentencia en Femenía López (2008: 131-167), Salas Carceller (2007: 467-472) y Cobas Cobiella (2008: 431-442), quien reconoce que las consecuencias y el fallo son a todas luces injustos, que la solución jurídicamente es correcta, «y aunque en un inicio me sedujo la tesis sostenida en el voto particular, meditando un poco sobre el tema, me parece más acorde a lo que la ley señala la tesis que en definitiva se ha contenido en el fallo de la sentencia que me ocupa» (2008: 442). 
El último pronunciamiento del Tribunal Supremo hasta la fecha, la Sentencia de 29 de abril de 2015, resuelve la demanda presentada por la hija ilegítima natural no reconocida del causante, solicitando la preterición no intencional, la anulación de la institución de heredero y la apertura de la sucesión intestada, y subsidiariamente la preterición intencional, reclamando lo que por legítima le corresponda. El causante había fallecido el 23 de enero de 1978 bajo testamento de 5 de noviembre de 1976 en el que instituía herederos a sus dos hijos matrimoniales y a su esposa. La actora había obtenido declaración judicial de la filiación paterna no matrimonial en 2008 una vez fallecido el causante. El Tribunal Supremo en aplicación de la redacción originaria del Código Civil confirma que la hija no matrimonial del causante carece de la condición de heredera forzosa y de todo derecho sucesorio. La sentencia tuvo un voto particular discrepante con el fallo y propicio a la aplicación del principio de igualdad y no discriminación por razón de filiación firmado por el magistrado Saraza Jimena, quien entiende que «la igualdad de los hijos constituye un principio básico del nuevo orden de convivencia, que puso término a una discriminación odiosa». La hija no matrimonial interpuso recurso de amparo, que ha dado lugar a la única sentencia específica sobre esta materia del Tribunal Constitucional 105/2017, de 18 de septiembre, denegando el amparo al estimar la Constitución como fecha de corte para la aplicación del principio constitucional de igualdad y no discriminación por razón de filiación.

De esta manera, la Sentencia del Tribunal Constitucional 105/2017, de 18 de septiembre, confirma la doctrina jurisprudencial. El Tribunal Constitucional reafirma, en contra del parecer del ministerio fiscal, la aplicación de las normas originarias del Código Civil, aunque otorguen un trato diferente a los hijos por razón de filiación:

[...] no puede entenderse expresiva de una discriminación por razón de nacimiento, sino solo como la expresión lógica de las consecuencias de un criterio legal sobre la ley rectora de la sucesión y de un parámetro de transitoriedad normativo fijado en 1981, ya en época constitucional. No existe, dicho de otro modo, una aplicación e interpretación judicial que desvelen una discriminación selectiva por razón de nacimiento, habiéndose limitado las resoluciones ahora recurridas a aplicar los criterios de sucesión y transitoriedad normativa, legalmente prescritos.

El principal argumento se basa en el criterio de la irretroactividad de la equiparación de los hijos respecto de la sucesión mortis causa del progenitor fallecido antes de la Constitución, para aplicar a través de la remisión de la disposición transitoria octava la legislación vigente en el momento de la apertura de la sucesión, es decir, a la fecha de fallecimiento del causante. 
En suma, cuando se trata de los derechos hereditarios derivados de las sucesiones abiertas con anterioridad a la entrada en vigor de la Constitución española, tanto el Tribunal Constitucional como el Tribunal Supremo son unánimes en considerar que no cabe aplicar la Constitución española con efecto retroactivo a sucesiones abiertas antes del 29 de diciembre de 1978, por lo que mantienen esta fecha de corte de modo tajante y radical ${ }^{17}$.

\section{RAZONES PARA LA NO DISCRIMINACIÓN DE LOS HIJOS NO MATRIMONIALES}

Las razones del Tribunal Constitucional y del Tribunal Supremo sobre el carácter irretroactivo de la Constitución española y la protección de la seguridad jurídica aparecen como legítimas y fundadas, para la no aplicación del principio de no discriminación por razón de nacimiento o filiación a los efectos de la sucesión hereditaria. Sin embargo, se puede analizar si resultan adecuadas, necesarias y proporcionadas en la relación existente entre la medida adoptada, el resultado producido y la finalidad pretendida, y si esas razones deben ceder ante otras que puedan ser prevalentes y justifiquen una equiparación en el trato de las distintas clases de filiación a los efectos sucesorios.

\section{LA APLICACIÓN DIRECTA DE LA CONSTITUCIÓN}

La doctrina jurisprudencial considera respecto a las sucesiones abiertas con anterioridad a la entrada en vigor de la Constitución que no cabe equiparar los derechos hereditarios de los hijos ilegítimos a los legítimos, y que admitir en estos casos la aplicación del art. 14 de la Constitución implicaría proclamar una retroactividad de grado máximo de la Norma Fundamental que su texto no contiene y, que con ello, se estaría quebrantando el principio de seguridad jurídica que también es un valor constitucional (STS 17 marzo 2005) ${ }^{18}$.

Ahora bien, no en todos los casos la aplicación de los principios constitucionales a sucesiones causadas antes de la entrada en vigor de la Constitución implica proclamar una retroactividad de grado máximo.

17 Recientemente, Espejo Lerdo de Tejada (2018: 436) valorándola positivamente afirma que esta doctrina puede considerarse definitiva.

18 En contra, Pizarro Moreno (2016: 385 ) defiende que «a lo mejor no hemos caído en la cuenta de que debía ser la aplicación retroactiva de la Constitución la única excepción al principio de seguridad jurídica. Y no solo, en sentido estricto, por el componente patrimonial». 
La jurisprudencia y la doctrina han apreciado distintos grados de retroactividad: una retroactividad mínima, otra de carácter medio y una de grado extremo o máximo. La retroactividad en grado mínimo o retroactividad impropia supone que la nueva regulación se aplica a los efectos de las situaciones creadas bajo la ley anterior que se producen con posterioridad a la entrada en vigor de la nueva, de modo que la nueva normativa solo tiene efectos para el futuro. La retroactividad de grado medio significa que la nueva ley se aplica a los efectos producidos antes de su entrada en vigor, pero que todavía no se han consumado, de modo que incide sobre efectos jurídicos de las situaciones anteriores ya producidos, pero todavía no agotados o consumados y que perviven tras el cambio legislativo. Y, la retroactividad de grado máximo o retroactividad auténtica se define como aquella en que la norma nueva anula o deshace los efectos producidos y consumados bajo la ley anterior, al tiempo que aplica la nueva ley a la relación o situación básica creada bajo el imperio de la norma antigua ${ }^{19}$.

La retroactividad de carácter mínimo o retroactividad impropia es aceptada pacíficamente por el Tribunal Constitucional y por el Tribunal Supremo. La retroactividad de grado máximo, en cuanto conduce a aplicar, sin más matización, una norma constitucional a una relación jurídica creada bajo el imperio de una legalidad anterior y con todos sus efectos agotados o consumados, es correctamente rechazada.

El mayor problema lo genera la retroactividad de grado medio en cuanto afecta a los efectos jurídicos todavía no agotados o consumados de situaciones creadas bajo la ley anterior, y la aplicación directa e inmediata de la Constitución española y de sus principios generales, en cuanto orden de convivencia, a situaciones originadas en el pasado que tienen efectos vigentes. Respecto a la aplicación directa e inmediata de la Constitución española, el Tribunal Constitucional ha entendido directamente aplicables los principios y derechos fundamentales recogidos en la Constitución, primando este criterio sobre la retroactividad de grado medio.

Así, la Sentencia del Tribunal Constitucional 80/1982, de 20 de diciembre, afirma que el art. 14 de la Constitución es de aplicación directa e

19 El Tribunal Constitucional y el Tribunal Supremo han tratado profusamente sobre la retroactividad de las leyes. Véanse las SSTC 9/1981 de 31 de marzo, 10/1981 de 6 de abril, 43/1982 de 6 de julio, 6/1983 de 4 de febrero, 72/1984 de 14 de junio, 42/1986 de 10 de abril, 99/1987 de 11 de junio, 227/1988 de 29 de noviembre, 210/1990 de 20 de diciembre y 182/1997 de 28 de octubre; y SSTS (Sala Tercera) de 22 de junio de 1994, de 18 de marzo de 1995, de 5 de febrero de 1996, de 15 de abril de 1997, de 26 de febrero de 1999 y de 17 de mayo de 1999. 
inmediata. La citada sentencia resuelve un recurso de amparo interpuesto por una hija no matrimonial contra la Sentencia del Tribunal Supremo de 8 de abril de 1982 por vulneración del art. 14 de la Constitución. El Tribunal Supremo había desestimado el recurso de casación presentado por la recurrente en amparo por entender caducada la acción de reclamación de su filiación no matrimonial a tenor de las normas originarias del Código Civil. En el supuesto el progenitor había fallecido en 1972, y la hija había interpuesto la demanda antes de la entrada en vigor de la Constitución española, que se produjo durante el proceso de apelación. A tal efecto, el Tribunal Constitucional entiende que

las dos sentencias impugnadas — casación y apelación — han aplicado, después de entrar en vigor la Constitución, el artículo 137 del Código Civil en su redacción anterior, y como éste contenía un criterio discriminatorio por razón de nacimiento contrario a la igualdad en un punto al régimen de las acciones de filiación, entre las pertenecientes a los hijos que pretendieran el reconocimiento a la filiación matrimonial o el de la extramatrimonial, tanto la sentencia de apelación como la de casación contienen fallos contrarios al derecho de igualdad que perpetúan en el presente posconstitucional un trato discriminatorio nacido al amparo de la legislación preconstitucional, por todo lo cual deben ser anuladas por este Tribunal [...]. Lo dicho hasta aquí no implica la aplicación retroactiva de la Constitución, sino el reconocimiento de su carácter normativo, el de la vinculatoriedad inmediata del artículo 14 y la afirmación de que, en consecuencia, todo español tiene, desde el momento mismo de la entrada en vigor de la Constitución, el derecho a no ser discriminado por razón de nacimiento, por lo cual no puede perpetuarse, vigente la Constitución, esta situación discriminatoria entre los regímenes contenidos en los artículos 118 y 137 del Código civil.

Igualmente, el Tribunal Constitucional acude a la aplicación directa de la Constitución en la Sentencia 35/1987, de 18 de marzo, sobre la protección de los derechos fundamentales de producción y creación artística y al honor (arts. 20.1.b y $18.1 \mathrm{CE}$ ) respecto a actos acaecidos con anterioridad a la entrada en vigor de la Constitución

[...] a pesar de no existir en la cláusula final de la Constitución, ni en ningún otro pasaje del Texto constitucional precepto alguno que establezca su retroactividad en términos generales o en relación con los derechos fundamentales, la Constitución tiene la significación primordial de establecer un orden de convivencia, singularmente en relación con derechos fundamentales y libertades públicas, debiendo por ello reconocerse que puede afectar a actos posteriores a su vigencia que deriven de situaciones creadas con anterioridad. 
Asimismo, el Tribunal Constitucional ha entendido de aplicación directa la Constitución y sobre todo sus principios fundamentales y, en concreto, el principio de igualdad a las situaciones pendientes en los tribunales. La Sentencia del Tribunal Constitucional 200/2001, de 4 de octubre, sobre la pension de orfandad para los hijos adoptivos, resume la doctrina constitucional sobre el principio de igualdad y no discriminación por razón de filiación, declarando que

[...] el artículo $14 \mathrm{CE}$ contiene en su primer inciso una cláusula general de igualdad de todos los españoles ante la Ley, habiendo sido configurado este principio general de igualdad, por una conocida doctrina constitucional, como un derecho subjetivo de los ciudadanos a obtener un trato igual, que obliga y limita a los poderes públicos a respetarlo y que exige que los supuestos de hecho iguales sean tratados idénticamente en sus consecuencias jurídicas y que, para introducir diferencias entre ellos, tenga que existir una suficiente justificación de tal diferencia, que aparezca al mismo tiempo como fundada y razonable, de acuerdo con criterios y juicios de valor generalmente aceptados, y cuyas consecuencias no resulten, en todo caso, desproporcionadas [...]. El principio de igualdad, no sólo exige que la diferencia de trato resulte objetivamente justificada, sino también que supere un juicio de proporcionalidad en sede constitucional sobre la relación existente entre la medida adoptada, el resultado producido y la finalidad pretendida». Particularmente, «dentro de la prohibición de discriminación por razón del nacimiento, este Tribunal ha encuadrado la igualdad entre las distintas clases o modalidades de filiación, de modo que deben entenderse absolutamente equiparadas éstas. Y directamente conectado con el principio constitucional de no discriminación por razón de filiación se encuentra el mandato constitucional recogido en el artículo 39.2 CE, que obliga a los poderes públicos a asegurar la protección integral de los hijos, iguales éstos ante la Ley con independencia de su filiación, de manera que toda opción legislativa de protección de los hijos que quebrante por sus contenidos esa unidad, incurre en una discriminación por razón de nacimiento expresamente prohibida por el artículo 14 de la Constitución, ya que la filiación no admite categorías jurídicas intermedias ${ }^{20}$.

20 La STC 200/2001, de 4 de octubre, estima la cuestión de inconstitucionalidad y la nulidad del inciso «para que la adopción pueda surtir efectos pasivos es preciso que el adoptante haya sobrevivido dos años, al menos, desde la fecha de la adopción» (art. 41.2 del Texto Refundido de la Ley de Clases Pasivas del Estado, aprobado por el Real Decreto Legislativo 670/1987, de 30 de abril).

En otras ocasiones, los tribunales no han reconocido la constitucionalización de la filiación por adopción. La STS 23 mayo 1991 sobre la filiación adoptiva había sostenido que «los arts. 14 y $39.2 .^{\circ} \mathrm{CE}$, no implican una constitucionalización de los derechos de los hijos en punto a su igualdad respecto de los padres más que en los que sean de la sangre, sin posible discriminación de si son intra o extra matrimoniales como se infiere 
En otras materias, el Tribunal Constitucional ha aplicado el principio de igualdad para no perpetuar situaciones discriminatorias precedentes. Así la Sentencia 158/1990, de 18 de octubre, extendió al viudo el derecho a la pensión de viudedad reconocida únicamente a las viudas. Los argumentos son interesantes, pues el Tribunal Constitucional no considera que se trate de dar efectos retroactivos al texto constitucional, sino de aplicar sus postulados desde su entrada en vigor a situaciones precedentes, desterrando definitivamente toda discriminación, de modo que aplica el art. $14 \mathrm{CE}$ sobre la normativa anterior, dado que el actor ha ejercitado la acción correspondiente dentro del plazo.

El Tribunal Constitucional soluciona la aplicación del principio de igualdad y no discriminación a situaciones nacidas con anterioridad a la Constitución española, con base en el criterio de la aplicación directa de los principios constitucionales que impide aplicar normas preconstitucionales contrarias a los principios fundamentales consagrados en la Constitución, sin que implique una aplicación retroactiva de la Norma Fundamental.

Pero, curiosamente, cuando se trata de los derechos sucesorios de los hijos ilegítimos y de los hijos naturales, el criterio cambia. Así se observa en la ya detallada Sentencia 105/2017, de 18 de septiembre, y también se deriva de la Sentencia 17/1981, de 1 de junio, sobre la posible inconstitucionalidad del art. 252 de la Compilación del Derecho civil de Cataluña (Ley 40/1960, de 21 de julio), por vulneración del principio de no discriminación por razón de

del art. 39.3 CE, pero sin que se configure un derecho de igualdad respecto de los adoptivos con relación a la familia del adoptante, pues tan sólo se define ese derecho de orden legitimario en la herencia del padre adoptante, y no por disposición constitucional obviamente, sino a través del art. 823 Cc según redacción de la Ley de 13 de mayo de 1981». Recurrida en amparo, el ATC 22/1992, de 27 de enero, lo inadmitió por carecer de carácter constitucional: «[...] se recurre una resolución judicial que lleva a cabo la interpretación de una disposición testamentaria, y tal interpretación testamentaria debe efectuarse conforme a la voluntad de la testadora, voluntad que no puede aislarse del momento histórico y legal en que se otorga el testamento. Por tanto, no es posible utilizar en la interpretación de tal llamamiento a la herencia, producido en el año 1931, conceptos actuales, que entonces no existían y que por ello no pudieron ser tomados en consideración por dicha testadora. En consecuencia, lo que la Sentencia impugnada pone de manifiesto es que, por una y otra de esas circunstancias, no cabría alegar la discriminación en que ahora se funda el amparo; debe así reputarse que la demanda carece manifiestamente de contenido constitucional».

En este sentido, Espejo Lerdo de Tejada (2014: 471) señala que «el principio constitucional de no discriminación no se refiere a los adoptados, y menos aún a los adoptados en forma simple» y que en el caso se trataba de la libertad de testar y de la interpretación de la voluntad del testador. 
nacimiento. Este artículo establecía la incapacidad relativa total para suceder de los hijos adulterinos, salvo un legado de alimentos (de forma similar a los arts. 139 y 845 de la redacción originaria del Código Civil). El Tribunal Constitucional no se pronuncia sobre la constitucionalidad de la norma cuestionada, porque de su validez no dependía el fallo (art. 35 LOTC), pero sobre la retroactividad de la Constitución hace la siguiente apreciación: «Es claro que los efectos que sobre la validez y la eficacia de las normas se derivan de su contradicción con la Constitución sólo surgen desde el momento en que se produce la contradicción misma, esto es, para las normas promulgadas con posterioridad a la Constitución, desde el momento de su entrada en vigor, y para las anteriores al texto constitucional, desde la fecha en que éste inició su vigencia ${ }^{21}{ }^{1}$.

Por tanto, el Tribunal Constitucional en materias diferentes a los derechos sucesorios de los hijos ilegítimos ha resuelto a favor de la aplicación directa del principio de igualdad a situaciones precedentes a su entrada en vigor o pendientes de litigio.

\section{EL ARGUMENTO DE LA CONSUMACIÓN O AGOTAMIENTO DE LOS EFECTOS SUCESORIOS}

La retroactividad de grado medio, en cuanto afecta a los efectos jurídicos todavía no agotados o consumados de situaciones creadas bajo la ley anterior, parece estar permitida en el párrafo primero de la disposición transitoria segunda LOTC, al establecer el plazo para «interponer el recurso de inconstitucionalidad o de amparo o promover un conflicto constitucional», admitiéndose que se puedan ejercitar contra «leyes, disposiciones, resoluciones o actos», que, siendo anteriores a la constitución del Tribunal Constitucional, «no hubieran agotado sus efectos ${ }^{22} »$.

21 Alonso García (1982: 9-10) considera que «la Constitución puede tener eficacia retroactiva siempre que las consecuencias de situaciones inconstitucionales perduren, afectando al ejercicio de derechos amparables, y siempre que no entren en juego intereses de terceros». Sobre la sentencia analizada, el autor entiende que no se puede aplicar la retroactividad del principio de igualdad en los derechos sucesorios porque "existen intereses en juego (los de los herederos legítimos)».

Por el contrario, la igualdad y no discriminación por razón de filiación no perjudica los derechos de los otros hijos en su cualidad de herederos forzosos, porque (todos) los hijos tienen derecho a la legítima global, y no a una cuota determinada de legítima, que dependerá del número de hijos del causante.

Fajardo Fernández (20I7: 70) interpreta la disposición transitoria 2a 1 LOTC, respecto a los derechos hereditarios de los hijos ilegítimos en sucesiones abiertas antes de la 
En este sentido, la doctrina jurisprudencial acepta la aplicación del principio de igualdad y no discriminación por razón de nacimiento a las sucesiones abiertas antes del 29 de diciembre de 1978 que no hubiesen agotado sus efectos. Sin embargo, realiza una interpretación especifica del agotamiento o de la consumación, propia de una retroactividad de grado mínimo o retroactividad impropia, en el sentido de que la nueva ley se aplica a los efectos que se producen después de entrada en vigor la Constitución española, de las sucesiones causadas antes de su entrada en vigor $^{23}$. En vez de entenderlo como retroactividad de grado medio, según la cual la nueva ley se aplicaría a los efectos que, producidos bajo la ley anterior, se prolongan en el tiempo y no se han consumado o agotado cuando entra en vigor la Constitución.

Así, la doctrina científica une en un mismo momento la apertura de la sucesión y su consumación o agotamiento, aunque tratan de la "consumación de la sucesión» precisamente respecto a la sucesión de los hijos no matrimoniales en caso de que el causante hubiese fallecido antes del 29 de diciembre de $1978^{24}$. Asimismo, la jurisprudencia considera que los efectos de la sucesión

entrada en vigor de la Constitución sucesiones: «Si no se puede pretender la aplicación de la Constitución frente a las situaciones jurídicas agotadas, es que sí se puede pretender frente a las no agotadas».

23 En este sentido, Fajardo Fernández (2017: 75) afirma que «debe aplicarse directamente el art. $14 \mathrm{CE}$ (en especial, cuando se trata de la igualdad de los hijos no matrimoniales) también a los derechos sucesorios de sucesiones que en el momento de la entrada en vigor de la $\mathrm{CE}$ se encontraban abiertas, pero no agotadas. $\mathrm{Y}$ un criterio razonable para admitir que una sucesión no estaba agotada en el momento de entrada en vigor de la $\mathrm{CE}$ es que posteriormente se haya tenido que realizar una delación sucesiva (prevista en testamento o no), o que en ese momento la herencia todavía no estuviera aceptada expresamente».

Un sector importante de la doctrina entiende que la sucesión se agota al momento del fallecimiento del causante, momento en que se produce la apertura de la sucesión y se determina la legislación aplicable, pero meramente a los efectos de los derechos sucesorios de los hijos ilegítimos. Así, Miquel González (1984) sostiene que «es claro que las sucesiones de los fallecidos antes de la Constitución no se ven afectadas ni por ésta ni por la reforma de 1981». Igualmente, Martínez-Calcerrada y Gómez (2007: I423) determina que «sólo cuando se produce ese fallecimiento se será heredero, y se tendrá derecho a la herencia en todo o parte, según "la Ley que rija en ese momento", lo cual determinará todo el entresijo de haberes, porciones o cuotas en la sucesión. Y de tal modo funciona esa convicción que, cuando se produce esa muerte, las cosas están pues ya definidas, y no parece que sea muy atendible, pretender que cualquier reforma ex post en esa legalidad entonces aplicable pueda variar o condicionar ni la cualidad hereditaria ni el derecho a recibir la herencia, porque al no existir ni conocimiento ni conciencia de esa futura legalidad no cabe cuestionar con ese evento futurible». 
se consuman o se agotan en el mismo momento de la apertura de la sucesión, al fallecimiento del causante, por lo que en todo caso por la remisión de la disposición transitoria octava se aplicaría la legislación originaria del Código Civil a las sucesiones en las que el causante falleció antes de la Constitución ${ }^{25}$.

No obstante, el fallecimiento del causante origina la apertura de la sucesión, que, seguida de las fases de la sucesión desde la aceptación hasta la partición y completa adjudicación de los bienes hereditarios, es un procedimiento que se prolonga en el tiempo ${ }^{26}$. Los «efectos de la sucesión» no pueden agotarse o consumarse antes de la efectiva adquisición de los bienes por los herederos ${ }^{27}$.

Seisdedos Muiño (2008: 96-97) señala que «existe una situación jurídica consolidada, y por tanto inmodificable por normas posteriores, desde el momento en que, por el solo hecho de la muerte del causante, sus derechos y obligaciones se transmiten y adquieren por los herederos, en virtud de lo establecido por los artículos 657 y 989 del Código civil». Hornero Méndez (2016: 329) sostiene que «de que una interpretación fiel y literal de la disposición transitoria octava hace innecesario todo este debate sobre si el fenómeno sucesorio está ya finalizado o no. La norma es escueta y sencilla, intencionadamente hay que pensar a estas alturas, y sitúa el punto de referencia en el fallecimiento del causante y la apertura de la sucesión que ésta acarrea. Ello debería bastar para determinar por qué norma han de regirse estos supuestos de reivindicación por parte de hijos extramatrimoniales de sus derechos sucesorios». Asimismo, Viteri Zubia (2017: 31) concluye que «la sucesión se rige, en consecuencia, por la ley vigente en el momento de la muerte del causante. Fallecido éste antes de la Constitución su sucesión se rige por el derecho anterior, tal y como establece la mencionada disposición transitoria octava, que permite que se mantengan las discriminaciones de la legislación anterior».

Por el contrario, O'Callaghan en su voto particular a la STS de 31 de julio de 2007 afirma que los efectos de la sucesión no se habían agotado antes de la entrada en vigor de la Constitución, aunque el causante había fallecido en 1976.

25 Véanse las SSTS de 10 de noviembre de 1987, de 13 de febrero de 1990 y de 17 de marzo de 2005.

26 La doctrina es unánime en la consideración del fallecimiento como momento de apertura de la sucesión (art. 657 CC). Albaladejo García (1990: 1) señala «la letra del art. 657 CC tiene el espíritu de que el derecho a suceder se adquiere al morir el de cuius. No se transmite, como dice el texto, porque tal derecho no pasa del causante al llamado, sino que nace para éste, pues aquél no lo tenía». Martín Pérez (2011: 242) lo denomina «inicio del fenómeno sucesorio» y reconoce que «se dilata en el tiempo». En este mismo sentido, véase Rubio Garrido (2013: 5031).

27 Así, la STS de 6 de noviembre de 1998 parece unir la consumación de la sucesión a la prescripción de la acción de petición de herencia, pues estima la acción de petición 
El Tribunal Supremo únicamente en la Sentencia de 1 de junio de 2016 se ha pronunciado a favor de la equiparación de los hijos matrimoniales y no matrimoniales en los derechos hereditarios cuando la sucesión se había abierto antes de la entrada en vigor de la Constitución. En el supuesto de autos se habían producido ulteriores vocaciones hereditarias y llamamientos concretos, una vez vigente la Constitución, por lo que se entiende que el efecto se ha producido con posterioridad a la entrada en vigor de la Constitución, y el Tribunal Supremo no puede evitar la aplicación de la retroactividad mínima o impropia, equiparando los derechos sucesorios de la filiación no matrimonial a la matrimonial. El procedimiento tuvo un largo recorrido. La causante había fallecido en 1966 sin legitimarios, con testamento notarial abierto y un caudal relicto con cuantiosos bienes muebles e inmuebles. En el testamento instituía como única heredera a la Orden de San Juan de Dios, sustituida vulgarmente por la Diputación Provincial de Albacete, con la condición testamentaria de constituir una fundación benéfica. La orden repudió la herencia, pasando a ser heredera, en segundo llamamiento, la Diputación Provincial. Sin embargo, debido al incumplimiento de la condición testamentaria, el nombramiento de heredero fue declarado decaído, por la Sentencia de la Audiencia Provincial de Albacete (Sección 2.a) de 15 de octubre de 2001, que mandó abrir la sucesión intestada. Conforme a ello, se inició procedimiento de jurisdicción voluntaria mediante Auto del Juzgado de Primera Instancia núm. 3 de Albacete de 28 de febrero de 2007, que declaró herederas intestadas a cinco parientes colaterales en cuarto grado de la causante, negando tal carácter a una prima hermana, hija natural de un tío de la causante, quien entabla procedimiento reclamando sus derechos hereditarios. La sentencia de primera instancia desestima la demanda, porque conforme al art. 943 del Código Civil (redacción originaria) el hijo natural no tiene derecho a suceder $a b$ intestato a los parientes legítimos del padre que lo haya reconocido. La Sentencia de la Audiencia Provincial de Albacete (Sección 2.a) de 10 de junio de 2014 estima el recurso de apelación y declara a la demandante heredera ab intestato; niega expresamente la aplicación de una norma contraria a la Constitución, al señalar que «no cabe que una norma discriminatoria sin causa legal y constitucionalmente legítima y relevante pueda aplicarse por un Tribunal, ya sea aquélla norma post como

de herencia entablada 43 años después del fallecimiento del padre por el hijo natural reconocido y desestima la prescripción. Sin embargo, no equipara a los hijos matrimoniales con el hijo natural, sino que, en la sucesión intestada del padre, le otorga la cuota que por el Código Civil (redacción originaria) le correspondía, es decir, la mitad de la cuota que recibe cada uno de los hijos matrimoniales (art. 942 que remite al art. 842 , ambos de la redacción originaria). 
preconstitucional; e incluso con mayor motivo debe impedirse si la norma es anterior a la Constitución ${ }^{28}$ ».

El Tribunal Supremo desestima el recurso de casación interpuesto por las parientes colaterales legitimas, y aplica el principio de igualdad y no discriminación, porque entiende que los efectos de esta sucesión —la apertura de la sucesión intestada - se han producido después de la entrada en vigor de la Constitución.

En el presente caso, la aplicación retroactiva del principio constitucional de igualdad o de no discriminación encuentra su fundamento primario en el hecho de que las relaciones sucesorias, atendidas las circunstancias del proceso sucesorio, no se encontraban consolidadas o agotadas antes de la entrada en vigor de la Constitución. En efecto, si atendemos a dicho proceso sucesorio, observamos que, con independencia del momento de apertura de la sucesión, que siempre viene determinado por el fallecimiento del causante, la dinámica sucesoria respondió a un orden sucesorio sucesivo determinado, consecutivamente y de forma independiente, por distintas vocaciones hereditarias [testamentaria y abintestada (sic), ambas válidas] y por distintos llamamientos concretos a su adquisición (ius delationis). De ahí que no pueda afirmarse que el fenómeno sucesorio, con relación a estos presupuestos del proceso sucesorio, estuviera consumado o agotado en el año 2001, cuando ya resultaba de aplicación la Constitución.

El ponente de esta sentencia, el magistrado Orduña Moreno resuelve en el mismo sentido y reproduciendo fragmentos de la Sentencia del Tribunal Supremo de 1 de marzo de 2013, de la que también había sido ponente. Esta sentencia contemplaba un supuesto de sustitución fideicomisaria con intervención de hijos adoptados. La litis comenzaba con el fallecimiento del causante en 1935 bajo testamento otorgado el mismo año, en el que nombraba herederos por partes iguales a sus dos hijos y establecía una sustitución simple a favor de sus respectivos hijos y descendientes legitimos, y otra sustitución fideicomisaria condicionada si sine liberis decesseris, en virtud de la cual se producía la sustitución entre los dos hijos herederos si alguno de ellos fallecía sin descendientes legitimos. Su primer hijo fallece con descendientes legítimos, mientras que el segundo fallece en 1991 con un hijo adoptado en forma «menos plena». Los herederos del primer hijo entienden que se cumple

28 Espejo Lerdo de Tejada (2018: 445) declara que es posible afirmar que «la STS de 1 de junio de 2016 resulta adecuada bajo la perspectiva de la jurisprudencia europea; en efecto, las exigencias que plantearía en nuestro caso la seguridad de los derechos adquiridos son absolutamente tenues y difícilmente justifican aplicar la norma preconstitucional». 
la condición y reclaman los bienes objeto de la sustitución fideicomisaria. Sin embargo, el Tribunal Supremo sostiene que, aun cuando en una sustitución fideicomisaria todos los sucesivos llamamientos fideicomisarios tienen lugar idealmente en el momento de la apertura de la sucesión del causante, «la definitiva adquisición de la herencia queda sujeta a la muerte del heredero fiduciario adoptante, y a la aceptación de la herencia fideicomisaria. En consecuencia, se trata de un "proceso adquisitivo, abierto y todavía no consolidado, en el que resulta pertinente la aplicación retroactiva del principio constitucional de igualdad o no discriminación (art. $14 \mathrm{CE}$ )», debiendo confirmar íntegramente la sentencia de la audiencia provincial que había reconocido derechos hereditarios a los herederos del hijo adoptivo del fiduciario. En consecuencia, aplica el principio de igualdad ante la ley respecto a los hijos adoptados, porque los efectos de la sucesión — la sustitución fideicomisaria- se habían producido con posterioridad a la Constitución española ${ }^{29}$.

A su vez, esta sentencia del Tribunal Supremo se había basado en la Sentencia del Tribunal Constitucional 9/2010, de 27 de abril, sobre la extensión a los hijos adoptivos de la condición de hijos legítimos, en sucesiones abiertas con anterioridad a la Constitución. En el supuesto de autos, el causante de vecindad catalana había fallecido en 1945 con testamento de 1927, en el que establecía una sustitución sometida a la condición si sine liberis decesseris entre sus cuatro hijos por orden sucesivo y sus descendientes hijos legitimos que llegasen a la edad de la pubertad, a salvo de la cantidad de siete mil pesetas que le servirán de pago de su porción legitimaria. Los dos primeros hijos fallecieron solteros y sin descendientes en 1997 y 1940, mientras que el tercer hijo había fallecido en 1995 con dos hijas adoptivas que ya habían alcanzado la edad de testar. Las hijas adoptivas reclaman frente al cuarto hijo, quien considera que las actoras no cumplen la condición del testamento de ser descendientes legitimos. La Sentencia del Tribunal Superior de Justicia de Cataluña de 22 de enero de 2004 confirmatoria de las sentencias de instancia había sostenido que «la expresión hijos legitimos no comprende a los hijos adoptivos» en lo que simplemente consideró que era la interpretación de la voluntad del testador. Por su parte, el Tribunal Constitucional considera la igualdad y no discriminación de los hijos adoptivos, una cuestión de carácter constitucional, y concede el amparo a las nietas adoptadas por vulneración del principio de igualdad por razón de filiación, pues entiende que no es posible que la filiación adoptiva quede excluida de la sustitución fideicomisaria ${ }^{30}$. No obstante, interpreta el

29 Véase el comentario a esta sentencia en Imaz Zubiaur (2014: 132-158).

30 Ahora bien, la STC 9/2010, de 27 de abril, cita la STEDH de 13 de julio de 2004 (caso Pla y Puncernau contra Andorra) alegada por la recurrente en amparo, que en un 
carácter adoptivo de las nietas de acuerdo "con el contexto social y jurídico en vigor en el que tomó efecto la disposición testamentaria (1996)», en vez de atender al momento de la redacción del testamento (1939). De manera que aplica el principio de igualdad vigente en 1996, cuando se produce un «efecto de la sucesión». El Tribunal Constitucional se centra en la aplicación directa del principio de igualdad, sin aludir a la normativa civil anterior o posterior a la Constitución, a la disposición transitoria octava, ni expresamente al agotamiento o consumación de los efectos. El fallo reenvía las actuaciones al momento anterior al de dictar la sentencia de primera instancia, "para que dicte otra sentencia respetuosa con el derecho fundamental de las recurrentes a no ser discriminadas por razón de su filiación ${ }^{31}$ ». La Sentencia 9/2010, de 27 de abril, cuenta con el voto particular del magistrado Rodríguez-Zapata Pérez con base en que la interpretación de la voluntad del testador «no entra por sí misma en colisión con el artículo 14 de la Constitución», sino que es acorde con el ejercicio de la libertad de testar ${ }^{32}$.

supuesto similar declara que los hijos adoptivos deben ser considerados hijos de legitimo y canónico matrimonio, por lo que estima existente una vulneración del principio de igualdad. Los tribunales andorranos habían negado derechos hereditarios a los hijos adoptivos del heredero fiduciario (hijo de la causante) dado que en el testamento se especificaba «descendientes de legítimo y canónico matrimonio». El Tribunal Europeo realiza una interpretación correctora por considerar que, en el momento en que se defiere la herencia por la muerte del fiduciario (1996), esta solución ya no puede sostenerse por ser contraria a los derechos humanos y, en consecuencia, los hijos adoptivos del heredero fiduciario deben ser considerados hijos de legítimo y canónico matrimonio; por lo que vulnera el art. 14 en relación con el art. 8 del Convenio. Véase un comentario a la sentencia en Arroyo i Amayuelas y Bondia García (2004: 7-88).

31 La SJPI de Vilafranca del Penedés de 14 de enero de 2011 concluye que «la doctrina constitucional no posibilitaba en el caso actual una interpretación de la expresión hijos legítimos que excluya a los adoptivos sino que debe abarcar tanto a la descendencia matrimonial como a la extramatrimonial y adoptiva puesto que resultaría un contrasentido que en este mismo plano de relaciones familiares las actoras pudieran suceder en la herencia de su padre pero no en la del abuelo, por su mera condición de ser hijas adoptivas. Lo expuesto conllevaba a considerar que las nietas adoptivas son herederas, en sustitución de su padre, del caudal hereditario procedente del causante». Este pronunciamiento es confirmado por la SAP de Barcelona (Sección 1.a) de 7 de mayo de 2013. El ATSJ de Cataluña de 14 de octubre de 2013 inadmite el recurso de casación.

32 Esta sentencia ha sido ampliamente criticada, pues no parece respetar la voluntad del testador, que cuando se refiere a hijos legitimos quiere significar hijos legitimos. Véanse Bercovitz Rodríguez-Cano (2010: 11), Espejo Lerdo de Tejada (2011: 244245) y Díez-Picazo Giménez (2014: 356-361); y los comentarios de Durán Rivacoba y Carbajo González (2012: 49-54), Espejo Lerdo de Tejada (2016: 621-663), Barrio 
En lo que afecta a los derechos sucesorios, el Tribunal Constitucional reconoce a las hijas adoptivas los mismos derechos sucesorios que a los hijos legítimos en una sucesión que, por la fecha de fallecimiento del testador en 1945, carecían de derechos hereditarios (art. 117 de la versión originaria del Código Civil ${ }^{33}$. Concede derechos hereditarios a las hijas adoptadas aplicando el principio de igualdad, en lugar de atender a la voluntad del testador ${ }^{34}$. Lo que contrasta todavía más con la no aplicación del principio de igualdad y no discriminación por razón de nacimiento y filiación en las sucesiones abiertas con anterioridad a la Constitución española. Únicamente la Sentencia del Tribunal Supremo de 1 de junio de 2016 equipara en derechos sucesorios a la filiación no matrimonial con la matrimonial, dado que la sustitución fideicomisaria acaeció en el año 2001, «efecto sucesorio» que tiene lugar cuando la Constitución ya estaba en vigor.

\section{EL CONTROL DE CONSTITUCIONALIDAD Y LA DISPOSICIÓN TRANSITORIA SÉPTIMA}

La disposición transitoria séptima de la Ley 11/1981, de 13 de mayo, determina que las acciones de filiación, en el caso de que el progenitor cuestionado o el hijo hubieran fallecido antes de entrar en vigor la ley se regirán

Gallardo (2016: 201-207), Fernández de Frutos (2011: 119-132), Herrero Oviedo (2012: 1-35), Romero Coloma (2011: 3319-3334) y Verdera Izquierdo (2011: 1-12).

33 Sobre los derechos hereditarios de los hijos adoptados en el Código Civil de 1889, reformado por las leyes de 1958, de 1970 y de 1987, véanse Albaladejo García (1988: 441-468), García-Bernardo Landeta (2002: 19-70), y la tesis doctoral de Sánchez-Rubio García (1994); y la STS de 23 de mayo de 1991 y la SAP de Burgos (Sección 2.º) de 11 de diciembre de 2006.

34 La STC analiza la interpretación de la voluntad del testador — que había otorgado testamento en 1927 - conforme a los principios constitucionales, en vez de interpretarla según el sentido literal de sus palabras, a tenor de lo dispuesto en el art. 675 CC. El testador, siempre que respete la institución legitimaria, puede disponer de sus bienes del modo que estime conveniente, sin estar vinculado por el art. $14 \mathrm{CE}$. En este sentido, Durán Rivacoba y Carbajo González (2012: 32) consideran que «las posibles dudas acerca de la extensión del término empleado con carácter genérico habrán de ser resueltas en la medida de lo posible sobre el apoyo que proporcione la voluntad cierta del causante, que podría estar movida por un ánimo restrictivo que habría que admitir, sea cual fuere el resultado alcanzado. Así, por ejemplo, la condición de que el fiduciario hubiese tenido hijos varones, contemplada y respetada en la STS 22 junio 2010, a propósito de una sustitución fideicomisaria de residuo si aliquid supererit, condicionada a que el fiduciario no tuviere descendencia masculina». 
exclusivamente por la legislación anterior. Su tenor literal es paralelo a la redacción de la disposición transitoria octava en relación con la ley aplicable a las sucesiones abiertas con anterioridad a la entrada en vigor de la ley. De modo que se puede establecer una similitud entre las disposiciones transitorias séptima y octava, respecto a las acciones de filiación y a la sucesión, que determinan que, si el pretendido padre falleció antes de la entrada en vigor de la Constitución, la posterior acción de filiación y la sucesión hereditaria se regirán por los preceptos del Código Civil que estuviesen vigentes al momento del fallecimiento. No obstante, la disposición transitoria séptima ha seguido un camino inverso a la trayectoria de la disposición transitoria octava.

En efecto, el Tribunal Constitucional tuvo oportunidad de pronunciarse sobre la disposición transitoria séptima en la Sentencia 80/1982, de 20 de diciembre. El recurso de amparo había sido interpuesto por la hija no matrimonial contra la Sentencia del Tribunal Supremo de 8 de abril de 1982. Esta sentencia había aplicado el art. 137 del Código Civil en su redacción originaria y entendido caducada la acción de reclamación de la filiación paterna no matrimonial con posesión de estado a su favor, interpuesta por la demandante después de que el pretendido progenitor hubiera fallecido en 1972. El Tribunal Supremo rechaza la petición de la demandante de elevar al Tribunal Constitucional una cuestión de inconstitucionalidad sobre la disposición transitoria séptima, por no cumplir los requisitos del art. 35 LOTC, al ser una norma de remisión, carecer de contenido sustantivo y no hacer depender la validez el fallo.

Entonces, fue la demandante quien presentó recurso de amparo, resuelto favorablemente por la Sentencia del Tribunal Constitucional 80/1982, de 20 de diciembre. La sentencia declara que

[...] antes de la promulgación de la Ley 11/1981, modificadora del Código Civil, que es en el momento en que tuvo que sentenciar la Audiencia Territorial de Sevilla, el artículo 137 había quedado derogado por el juego del artículo 14 y la disposición derogatoria tercera de la Constitución, y, partiendo de este planteamiento, debió resolver la Audiencia y después debió enjuiciar su sentencia la Sala Primera del Tribunal Supremo, porque la inconstitucionalidad sobrevenida del artículo 137 genera su nulidad y produce necesariamente efectos incluso sobre los procesos pendientes, actuando así como límite al principio según el cual un proceso debe resolverse con arreglo a la legislación vigente en el momento de la interposición de la acción.

El Tribunal Constitucional estima el amparo y reenvía las actuaciones a la Audiencia Territorial de Sevilla, que vuelve a fallar de nuevo, pero esta vez estimando el recurso de apelación y declarando que «la demandante es hija por naturaleza extramatrimonial del causante, con todas sus consecuencias 
legales». Los demandados recurren en casación la declaración de filiación. El Tribunal Supremo, mediante Sentencia de 10 de marzo de 1987, resuelve confirmando únicamente la filiación combatida, sin entrar en la cuestión de los derechos sucesorios. En la demanda originaria del primer procedimiento civil, se habían solicitado los derechos sucesorios reconocidos por la ley a los hijos naturales, pero como la hija era natural no reconocida, la ley no le otorgaba ningún derecho sucesorio.

Tras la Sentencia 80/1982, de 20 de diciembre, la disposición transitoria séptima se ha vaciado de contenido, al entenderse derogados por inconstitucionalidad sobrevenida los preceptos del Código Civil originarios que sean contrarios a los derechos fundamentales. En consecuencia, el Tribunal Supremo de conformidad con la doctrina constitucional considera que no cabe aplicar la disposición transitoria séptima, y aplica en su lugar la legislación posconstitucional a todas las acciones de filiación que se ejercitan, aunque el progenitor cuestionado o el hijo hubiesen fallecido antes de la Constitución ${ }^{35}$. Por tanto, entiende inaplicables por inconstitucionales los arts. 137, 139, 140 y 141 del Código Civil en su versión originaria ${ }^{36}$.

Así, la Sentencia del Tribunal Supremo de 7 de julio de 2004 confirma la declaración de filiación paterna no matrimonial de las dos actoras respecto a su padre fallecido en 1977. Reitera la doctrina de la Sentencia del Tribunal Constitucional 80/1982, de 20 de diciembre, que «declara inconstitucional el artículo 137 del Código civil en su redacción anterior por cuanto establecía discriminaciones por razón de nacimiento contrarias a la igualdad en relación con las acciones de filiación, doctrina que obliga a que deba entenderse derogada por anticonstitucional cualquier discriminación contraria, análoga a la señalada por aplicación del artículo 14 y la disposición derogatoria tercera $\mathrm{CE}$ », por lo que "no se pueden aplicar al caso normas o prohibiciones normativas que como las referentes a plazos de caducidad de las acciones o denegar las acciones para la determinación de la filiación o imponer restricciones a la

35 La STS de 24 de diciembre de 1996 confirma la interpretación de la disposición transitoria séptima, aunque el fallo desestime la declaración de filiación por falta de prueba. El actor había interpuesto demanda solicitando la reclamación de filiación no matrimonial y la declaración de heredero del causante fallecido en 1977. El juzgado consideró ambos pedimentos irreconciliables, ciñéndose el procedimiento a la acción de filiación.

36 Rivero Hernández (1995: 243) reconoce que «los llamados bajo la vieja legalidad hijos ilegitimos tienen acción para reclamar su verdadera filiación toda su vida, como ocurre para los legítimos conforme al art. 118 CC en su versión anterior, y estima derogados, por contrarios a la Constitución, los arts. 139 a 141 CC (también versión originaria)». 
legitimación que impliquen un trato diferencial no justificado en perjuicio de los hijos no matrimoniales».

En este punto, la interpretación del Tribunal Supremo sobre la disposición transitoria séptima y octava es diametralmente opuesta. Respecto a la disposición transitoria séptima la afirmación de la Sentencia de 19 de mayo de 1997 no necesita comentario:

Es evidente que no puede hablarse entonces de situaciones consolidadas a fin de mantener a los hijos ilegítimos en esta categoría durante toda su vida, por el hecho de su progenitor hubiese fallecido antes de la entrada en vigor de la Constitución. Por el contrario, desde ese momento, y por virtud de su disposición derogatoria tercera, no podían sufrir ninguna discriminación en sus derechos frente a los hijos matrimoniales, han salido, en otras palabras, de la situación lamentable en que los colocaba unas arcaicas concepciones sociales sobre las que se basaban los viejos preceptos del Código civil. Así las cosas, cuando la disposición transitoria séptima de la Ley de 13 de mayo de 1981 se remite a la legislación anterior para determinar el régimen de las acciones de filiación si el progenitor o el hijo ha fallecido antes de la entrada en vigor de la referida Ley, ha de ser interpretada en función de la derogación que el texto constitucional había producido en el texto del Código civil, lo que lleva a la consecuencia de que los hijos extramatrimoniales que antes eran ilegítimos pueden ejercitar la acción de determinación de su verdadera filiación, y en cuanto al plazo, que no pueden sufrir un trato discriminatorio respecto de los matrimoniales (legítimos en la antigua terminología $)^{37}$.

Curiosamente las disposiciones transitorias séptima y octava también se distancian respecto a la interpretación temporal de los hechos acaecidos con anterioridad a la Ley 11/1981. Con relación a la disposición transitoria séptima se declara la derogación por inconstitucionalidad sobrevenida de los preceptos originarios del Código Civil, de tal modo que para la reclamación de la filiación no se establece diferencia alguna en el caso de que el pretendido padre hubiera fallecido antes de la entrada en vigor de la Constitución o después, ni tampoco claramente con relación a la entrada en vigor de la Ley 11/1981.

Por lo que se refiere a la interpretación de la disposición transitoria octava de la Ley 11/1981, de 13 de mayo, la jurisprudencia distingue tres situaciones: a) las sucesiones abiertas antes de la entrada en vigor de la Constitución que se rigen por la normativa del Código Civil en su redacción originaria, con diferencia de trato entre filiación legítima, natural e ilegítima; b) las sucesiones abiertas entre la Constitución y la Ley de 13 de mayo de 1981, en las que se

37 La STS de 19 de mayo de 1997 no declara la filiación paterna no matrimonial reclamada respecto al pretendido padre fallecido en 1960, por falta de prueba. 
aplica a la sucesión mortis causa el Código Civil en su redacción originaria, pero conforme a los principios constitucionales sin discriminación por razón de nacimiento y filiación (arts. 14 y 39.2 CE), y c) las sucesiones abiertas con posterioridad a la entrada en vigor de la Ley 11/1981, que se rigen por la nueva redacción del Código Civil.

Esta diferencia de tratamiento dispensado a las acciones de filiación y al fenómeno sucesorio es paradójica, pues, en un mismo supuesto, la fecha del fallecimiento del testador resulta irrelevante a efectos del ejercicio de las acciones de filiación, pero totalmente determinante para el derecho aplicable a la sucesión del progenitor ${ }^{38}$. Por tanto, la aplicabilidad del art. 14 de la Constitución tiene lugar solo en lo referente a la declaración de la filiación, pero no respecto a los derechos sucesorios. Así, se producen situaciones como la recogida en la Sentencia del Tribunal Supremo de 28 de julio de 1995, que estima la declaración de filiación paterna no matrimonial, considerando inaplicable la disposición transitoria séptima, y aplica la remisión de la disposición transitoria octava para negar a los actores derechos sucesorios. El causante había fallecido el 4 de febrero de 1978 con testamento de fecha de 21 de julio de 1976 , en el que instituía heredera universal a una hija natural reconocida. Abierta la sucesión, los cuatro actores solicitan la declaración de su filiación no matrimonial, la nulidad del testamento por preterición y su condición de herederos ab intestato. Las sentencias de instancia habían declarado la filiación extramatrimonial de los actores y su derecho a la parte proporcional de la legítima estricta, declarando válido el testamento hecho a favor de la hija natural reconocida. El Tribunal Supremo confirma la declaración sobre la filiación paterna de los actores, pero casa la sentencia de apelación en cuanto a los derechos hereditarios, aplica la legislación originaria del Código Civil por remisión de la disposición transitoria octava, y falla estableciendo que los actores carecen de derechos sucesorios, dado que no eran hijos reconocidos.

Más grave resulta la opuesta apreciación que sobre algunos preceptos originarios del Código Civil realiza el Tribunal Supremo. Por un lado, en sede de filiación, los arts. 137, 139, 140 y 141 de la versión originaria del Código Civil se consideran derogados por inconstitucionalidad sobrevenida según la

38 Barber Cárcamo (2013: 53) y Hornero Méndez (2016: 324-325) destacan las razones que justifican el diferente tratamiento dispensado a las disposiciones transitoria séptima y octava: la irretroactividad de la norma constitucional, proclamada de modo general por la propia Constitución y ratificada por el Tribunal Constitucional y la aplicación de una única ley a todo el fenómeno sucesorio (art. 657 CC). Espejo Lerdo de Tejada (2006: 396-397) se muestra acorde con la diferencia de interpretación entre ambas disposiciones, con base en «la estabilidad de las situaciones sucesorias ya consolidadas". 
disposición derogatoria tercera de la Constitución española (SSTS de 17 de marzo de 1995, de 19 de mayo de 1997 y de 7 de julio de 2004); mientras que, por otro, el mismo art. 139 es aplicado para negar derechos sucesorios a los hijos ilegítimos no naturales, como en la Sentencia de 31 de julio de 2007.

En suma, a la vez que la doctrina jurisprudencial ha obviado la aplicación de la disposición transitoria séptima, permitiendo que todas las acciones de filiación se rijan por el Código Civil en su redacción de 1981, en cuanto a sus requisitos de legitimación y plazos de caducidad, para que no se discrimine la filiación no matrimonial cuando el padre había fallecido antes de la Constitución española, la doctrina jurisprudencial ha mantenido firme la remisión de la disposición transitoria octava al conjunto de la normativa civil de las sucesiones mortis causa abiertas antes de la Constitución, aplicando los arts. 807-808, 840-847, 931 y 939-945 de la redacción originaria del Código Civil.

Desafortunadamente, los órganos de la jurisdicción ordinaria no han realizado el control sobre las leyes preconstitucionales, recordado por el Tribunal Constitucional en la Sentencia 155/1987, de 14 de octubre, en concreto sobre los arts. 807, 808, 840 a 847, 931 y 939 a 945 de la versión originaria del Código Civil, pues se hubieran podido declarar inaplicables por inconstitucionalidad sobrevenida según la disposición derogatoria tercera de la Constitución española ${ }^{39}$. En efecto, el Tribunal Constitucional no pudo declarar la inconstitucionalidad de la disposición transitoria octava, pero en vez de inadmitir el recurso, entró en el fondo del asunto, se lamentó de que no se hubiera requerido la declaración de inconstitucionalidad de preceptos concretos del Código Civil en su versión originaria, y dejó abierta la posibilidad de que se consideren derogados por inconstitucionalidad sobrevenida los preceptos sucesorios del Código Civil que introducen una diferencia de trato por razón de nacimiento entre los distintas clases de filiación.

El control por los órganos de la jurisdicción ordinaria de las leyes preconstitucionales debería conllevar la inaplicación por inconstitucionalidad sobrevenida de los artículos del Código Civil que contienen un trato diferente por razón de filiación a los efectos de los derechos sucesorios, a tenor de

39 De los procedimientos que han llegado al TS, algunas sentencias de instancia habían fallado concediendo derechos sucesorios a los hijos ilegítimos, así, de la STS de 28 de julio de 1995, reconocieron los derechos sucesorios las SJPI de Priego de 29 de mayo de 1990 y la SAP de Sevilla (Sección 6. a) de 3 de diciembre de 1991; de la STS de 17 de marzo de 2005, la SJPI núm. 4 de La Coruña de 3 de julio de 2000; y de la STS de 31 de julio de 2007, la SJPI núm. 10 de Las Palmas de 16 de julio de 1999 y SAP de Las Palmas (Sección 5.a) de 11 de mayo de 2000. 
la disposición derogatoria tercera de la Constitución española. Esta afirmación no determina la aplicación del Código Civil en su redacción posterior a 1981 a las sucesiones abiertas con anterioridad a dicha fecha, sino al igual que las sucesiones abiertas entre la entrada en vigor de la Constitución y la Ley 11/1981, de 13 de mayo, se deben adaptar dichos preceptos a los principios constitucionales. Además, no se trata de reabrir todas las sucesiones anteriores a la Constitución española, sino de aplicar en la época posconstitucional el principio de igualdad y no discriminación por razón de nacimiento y filiación a aquellas sucesiones, que, con independencia del momento en que se abrieron por el fallecimiento del causante, prolongan sus efectos o tienen pendiente un procedimiento judicial.

\section{LA EXCEPCIÓN DE ORDEN PÚBLICO}

Es comúnmente admitido que el orden público español está integrado por los derechos fundamentales y las libertades públicas garantizados en la Constitución ${ }^{40}$. Asimismo, es aceptado en concreto un orden público

40 El orden público ha sido estudiado profusamente por los estudiosos del derecho internacional, véanse González Campos y Fernández Rozas (1995: 917), Álvarez González (2015: 150), Carrascosa González (2008: 2360) y Corriente Córdoba (1975: 188). Asimismo, ha sido analizado por la jurisprudencia. «El orden público, que está constituido por los principios jurídicos, públicos y privados, políticos, morales y económicos, que son absolutamente obligatorios para la conservación del orden social en el pueblo y en una época determinada» (SSTS de 5 de abril de 1966 y de 31 de diciembre de 1979). «Una notable concepción de la doctrina científica aprecia como tal los principios o directivas que en cada momento informan las instituciones jurídicas; asimismo, una moderna posición de la ciencia jurídica señala que el orden público constituye la expresión que se le da a la función de los principios generales del derecho en el ámbito de la autonomía privada, consistente en limitar su desenvolvimiento en lo que los vulnere, y que, básicamente, hoy han de tenerse en cuenta, como integrantes del orden público, los derechos fundamentales reconocidos en la CE» (STS de 5 de febrero de 2002). Efectivamente, la noción de orden público ha estado íntimamente ligada al respeto de los derechos y libertades reconocidos constitucionalmente y los principios constitucionales básicos (SSTC 54/1989, de 23 de febrero, y 81/1992, de 28 de mayo).

Sobre el orden público en materia sucesoria, la STS de 8 de octubre de 2010 define el orden público como «un concepto indeterminado que engloba el conjunto de valores o principios que inspiran y presiden el ordenamiento nacional, funcionando como pauta para su funcionamiento correcto. Puede considerarse que orden público indica las condiciones mínimas a las cuales está subordinada la existencia del ordenamiento jurídico, son las condiciones que operan para la tutela de la integridad del ordenamiento 
compuesto por los principios fundamentales sobre la familia, dentro del cual tienen anclaje diversos preceptos constitucionales como el derecho al libre desarrollo de la personalidad (art. 10.1 CE), el derecho a contraer matrimonio (art. $32 \mathrm{CE}$ ), derecho a la intimidad familiar (art. 18.1 CE), la protección de la familia (art. 39.1 CE) y la protección integral de los hijos, iguales estos ante la ley con independencia de su filiación (art. 39.2 CE) ${ }^{41}$.

El orden público funciona no solo como principio general y fundamental de nuestro ordenamiento ${ }^{42}$, sino que ostenta un papel relevante en la protección de los principios fundamentales superiores, impidiendo a través de la excepción de orden público que se reciban en España actos que puedan vulnerar las reglas básicas del Estado de derecho ${ }^{43}$.

En este sentido, el orden público internacional español ha sido invocado en el ámbito sucesorio en la Resolución de la Dirección General de los Registros y del Notariado de 20 de julio de 2016. Resuelve sobre la inscripción de una escritura notarial de formalización de operaciones particionales de la herencia de un nacional iraní fallecido con última residencia en España con un hijo y una hija. La sucesión intestada se rige por el derecho iraní, conforme al cual corresponde a los varones doble porción en la herencia de su padre que a las hijas. Presentada la escritura pública de partición con la aquiescencia del hijo y de la hija, el registrador no admite inscribir la copia autorizada de la

jurídico. Lo que no es otra cosa que el sistema ideal de valores en el que se inspira el ordenamiento jurídico en su totalidad implica un carácter absolutamente obligatorio e inderogable del mismo y lleva consigo una función excluyente, de impedir que tengan eficacia jurídica y que puedan integrarse en el ordenamiento normas extranjeras que lo contraríen".

41 García Presas (2011: 241) y Viguri Perea (2016: 860) defienden un «orden público familiar».

El orden público de carácter familiar existía antes de la Constitución española, aunque con contenido diferente. Véase la STS de 10 de octubre de 1960, que consideró de orden público la diferencia de trato en la sucesión ab intestato de un español respecto a una hija adulterina de un hermano del causante, habida y legitimada en Cuba.

42 La jurisprudencia ha reconocido que las cuestiones filiales y el estado civil de filiación son de orden público. El Tribunal Supremo ha acudido al orden público del estado civil de filiación, para determinar el conflicto de intereses entre los progenitores y el hijo (SSTS de 7 de noviembre de 2002, de 17 de enero de 2003, de 5 de noviembre de 2003 y de 9 de julio de 2004), para conceder acción de reclamación y de impugnación de la paternidad al padre no matrimonial (STS de 5 de noviembre de 1987) o a la madre que actuaba como representante de su hijo (STS de 28 de noviembre de 1992). La STS de 22 de marzo de 2000 deja claro que «el orden público del foro ha de ser observado y protegido por los Tribunales españoles». 
escritura de aceptación y adjudicación de la herencia «en la que se aplica sin más la ley extranjera», y califica negativamente el título al considerar que «la normativa nacional del causante vulnera el orden público internacional español y no puede ser aplicada en España, pues falta causa en el exceso de adjudicación a favor del heredero varón». Recurrida por los dos hijos, el Centro Directivo confirma la calificación del registrador al sostener que

la aplicación en España de la norma extranjera es incompatible con los principios fundamentales o ideas eje que fundamentan el ordenamiento jurídico español como el principio de no discriminación recogido tanto en el artículo $14 \mathrm{CE}$ como en los relevantes convenios internacionales ${ }^{44}$, normas que no sólo informan con carácter de principio orientador el ordenamiento jurídico, sino que son de aplicación directa en España, estando obligadas las autoridades españoles a garantizar el respeto a los principios indicados al valorar los resultados de la aplicación a que llama la norma de conflicto, por lo que no es posible atribuir efecto jurídico en España a una norma discriminatoria ni en la esfera judicial ni en la extrajudicial. Constituye, por tanto, manifestación del orden público internacional del foro la interdicción de una situación discriminatoria como la planteada teniendo en cuenta además la especial vinculación del supuesto con el ordenamiento jurídico español ${ }^{45}$.

Este supuesto es muy interesante, pues la Dirección General considera que la normativa iraní es discriminatoria para la mujer y, por lo tanto, contraria al orden público de España; de la misma manera que se podría entender que la aplicación de los arts. 139, 807, 808, 840 a 847, 931 y 939 a 945 de la redacción originaria del Código Civil por remisión de la disposición transitoria

44 Entre los que cita el art. 2 de la Declaración Universal de los Derechos Humanos, el art. 21 de la Carta de los Derechos Fundamentales de la Unión Europea de 7 de diciembre de 2000 y el art. 14 del Convenio Europeo para la protección de los derechos humanos y de las libertades fundamentales; además del principio general del derecho de la Unión Europea conforme al art. 6 del Tratado de Funcionamiento de la Unión Europea.

Aguilar Benítez de Lugo y Aguilar Grieder (2005: 1140) señalan con carácter general que «la vulneración manifiesta de los principios y valores contenidos en nuestra Constitución, por las normas islámicas relativas a las sucesiones ab intestato, no sólo faculta, sino que obliga a los órganos jurisdiccionales españoles a aplicar nuestra cláusula de orden público».

En contra, Álvarez González (2016: 8 y 16) no considera de aplicación la excepción de orden público, con base en la autonomía de la voluntad manifestada en la conformidad de la hija.

Para un comentario de esta resolución, véase Moreno Sánchez-Moraleda (2017: 355370). 
octava, en cuanto contienen una diferencia de trato por razón de filiación, resulta contraria al orden público español.

La excepción de orden público español también ha sido opuesta en la Sentencia de la Audiencia Provincial de Barcelona (Sección 4.a) de 28 de octubre de 2008 para evitar una diferencia de trato por razón de nacimiento en los derechos sucesorios respecto a la legislación marroquí, que discrimina por razón de filiación matrimonial y no matrimonial, además de por razón de sexo y de religión. La sentencia equipara en derechos hereditarios a la hija, en contra de lo establecido en la legislación marroquí, pues la hija provenía del matrimonio de un musulmán con una no musulmana, que por motivos religiosos no había sido reconocido oficialmente en Marruecos, por lo que era considerada hija nacida fuera del matrimonio. "Por lo que debemos aplicar la regla del orden público prevista en el artículo 12.3 del Código civil que permite no aplicar la ley extranjera cuando resulte contraria al orden público por colisionar con los principios básicos del ordenamiento jurídico español ${ }^{46}$ \%.

La excepción de orden público en el ámbito sucesorio puede cobrar gran importancia, máxime desde que resulta aplicable el Reglamento (UE) núm. 650/2012 del Parlamento Europeo y del Consejo de 4 de julio de 2012 relativo a la competencia, la ley aplicable, el reconocimiento y la ejecución de las resoluciones, a la aceptación y la ejecución de los documentos públicos en materia de sucesiones mortis causa y a la creación de un certificado sucesorio europeo ${ }^{47}$, que amplía las posibilidades de su aplicación cuando los tribunales españoles por ser competentes de acuerdo con el reglamento deban resolver sucesiones conforme a la ley de un Estado miembro de la Unión Europea o de un tercer Estado. O, en su caso, cuando resulte aplicable la ley española para la determinación de la filiación, y una ley extranjera para la sucesión en la que los hijos matrimoniales tengan más derechos sucesorios que los hijos no matrimoniales.

En suma, el principio de igualdad y no discriminación por razón de nacimiento y la protección integral de los hijos, iguales ante la ley con independencia de su filiación, que se configura como límite a los operadores jurídicos españoles por ser norma de orden público, debería configurarse como tal, en la aplicación por los tribunales españoles de las normas preconstitucionales del Código Civil que contienen un trato diferente de los hijos ilegítimos en

46 Para un comentario de esta sentencia, véase Oró Martínez (2009: 287-304).

47 El presente Reglamento es aplicable desde el 17 de agosto de 2015, sin perjuicio de que algunos artículos hayan sido aplicados con anterioridad (arts. 79, 80 y 81 desde el 5 de julio de 2012 y arts. 77 y 78, desde el 16 de enero de 2014). 
los derechos sucesorios ${ }^{48}$. En efecto, así como se rechaza la aplicación de una ley extranjera por ser contraria al orden público español se debería denegar la aplicación de las normas del Código Civil anteriores a la Constitución española que por no respetar el principio de igualdad y los derechos y libertades fundamentales resultan contrarias al orden público.

\section{LA DENOMINADA DISCRIMINACIÓN INDIRECTA}

La discriminación indirecta es el principal argumento del voto particular formulado por el magistrado Valdés Dal-Ré a la Sentencia del Tribunal Constitucional 105/2017, de 18 de septiembre, de la que fue ponente. En contra de la afirmación de la sentencia: «no existe, dicho de otro modo, una aplicación e interpretación judicial que desvelen una discriminación selectiva por razón de nacimiento, habiéndose limitado las resoluciones ahora recurridas a aplicar los criterios de sucesión y transitoriedad normativa, legalmente prescritos». El voto considera que ha habido una discriminación indirecta, porque la única razón para denegar el amparo era el carácter ilegítimo de la filiación.

48 La doctrina internacionalista ha estudiado esta materia. Blázquez Rodríguez (2009: 451-452) considera que en estos casos los tribunales españoles deberían rechazar la aplicación de la ley extranjera a través de la excepción de orden público internacional: «[...] nuestra Constitución es clara en su art. 39.2 al encargar a los poderes públicos la protección integral de los hijos, iguales éstos ante la ley, con independencia de su filiación. De igual modo, según la jurisprudencia del TEDH en aquellos casos en que exista una desigualdad sucesoria entre hijos legítimos e ilegítimos se produce una violación de los arts. 8 y 9 del Convenio, consagrando la intervención del orden público internacional frente a las legislaciones estatales que amparen dicha desigualdad [...]. Los principios de igualdad y de libertad religiosa proclamados por nuestra Constitución servirán de base para la intervención del orden público frente a la ley sucesoria extranjera que inhabilite para heredar por la no pertenencia a un determinado credo, ampare una mayor participación en el caudal relicto del varón frente a la mujer o excluya a determinados hijos bajo su consideración de ilegitimos».

En un sentido similar, Aguilar Benítez de Lugo y Aguilar Grieder (2005: II35) sostienen que «con la reforma del Código civil en materia de filiación operada por la Ley $11 / 1981$, de 13 de mayo, se ha producido una equiparación de la filiación matrimonial y la no matrimonial en cuanto a sus efectos. Esa reforma ha venido a suponer una superación de la discriminación anteriormente existente entre las diversas clases de filiación (filiación legítima e ilegítima, natural y no natural), cerrando el paso a la intervención del orden público. Esa reforma del Código civil, equiparando las distintas clases de filiación, al amparo del principio de igualdad constitucional, suscita la posible intervención del orden público frente a una legislación extranjera que discrimine entre los hijos, suprimiendo o restringiendo los derechos sucesorios de los hijos naturales». 
La conclusión alcanzada por el Tribunal Supremo en la sentencia recurrida subraya que la sucesión se produjo con anterioridad a la entrada en vigor de la Constitución Española y que eran de aplicación, entonces, las disposiciones transitorias que al respecto establecía la reforma de 1981 del Código civil. Ahora bien, ese juicio sobre la discriminación directa no colma, sin embargo, el mandato constitucional de prohibición de discriminación por razón de filiación (art. $14 \mathrm{CE}$ ). La vulneración del derecho fundamental aludido también debe declararse cuando la norma, o una interpretación judicial de la misma formalmente neutra en el trato a unos y otros hijos, ocasione en los hijos extramatrimoniales un impacto o resultado adverso. Es la denominada discriminación indirecta, aquí, por razón de filiación.

En efecto, con anterioridad el Tribunal Constitucional había afirmado que la prohibición del art. 14 de la Constitución española comprende no solo la discriminación directa o patente derivada del tratamiento jurídico manifiesta e injustificadamente diferenciado y desfavorable de unas personas respecto a otras, sino también la discriminación encubierta o indirecta consistente en aquel tratamiento formal o aparentemente neutro o no discriminatorio del que se deriva, por las diversas circunstancias de hecho concurrentes en el caso, un impacto adverso sobre la persona objeto de la práctica o conducta constitucionalmente censurable en cuanto la medida que produce el efecto adverso carece de justificación al no fundarse en una exigencia objetiva e indispensable para la consecución de un objetivo legítimo o no resultar idónea para el logro de tal objetivo. En este sentido, la Sentencia 203/2000, de 24 de julio, estima el recurso de amparo por discriminación indirecta por razón de sexo, y la Sentencia 13/2001, de 29 de enero, se manifiesta conforme con la doctrina sobre la discriminación indirecta por razón de raza, aunque en el supuesto desestima el amparo por no apreciar la existencia de vulneración ${ }^{49}$.

La discriminación indirecta no solo pretende evitar la discriminación por razón de sexo, raza o discapacidad ${ }^{50}$, sino que también acoge la discriminación

49 Sobre la interdicción de la discriminación indirecta en el art. 14 CE, véanse las SSTC 253/2004, de 22 de diciembre, y 69/2007, de 16 de abril.

50 La discriminación indirecta, acuñada sobre todo en el ámbito laboral para evitar la discriminación por razón de sexo, raza o discapacidad «existe cuando una disposición legal o reglamentaria [...] aparentemente neutra, pueda ocasionar una desventaja particular a una persona respecto de otras por motivo de o por razón [de filiación], siempre que objetivamente no respondan a una finalidad legítima y que los medios para la consecución de esta finalidad no sean adecuados y necesarios» (véase art. 2 del Real Decreto Legislativo 1/2013, de 29 de noviembre, por el que se aprueba el Texto Refundido de la Ley General de derechos de las personas con discapacidad y de su inclusión social). Véase también el art. 28 de la Ley 62/2003, de 30 de diciembre, de medidas fiscales 
por razón de filiación. Así, lo establece la Sentencia del Tribunal Constitucional 154/2006, de 22 de mayo, al estimar el amparo contra la negativa a la concesión de la indemnización de orfandad a favor del hijo extramatrimonial por fallecimiento de su padre en un accidente de tráfico. El Tribunal Constitucional considera vulnerado el principio de igualdad por razón de su filiación extramatrimonial (art. $14 \mathrm{CE}$ ) y discriminatoria la aplicación de la legislación vigente que acogía dicha diferencia de trato. La argumentación a favor de la igualdad ante la ley resulta clara:

[...] toda opción legislativa de protección de los hijos que quebrante por sus contenidos esa unidad —lo mismo que aquellas interpretaciones de la regulación legal que la determinen - ocasionan una discriminación por razón de nacimiento expresamente prohibida por el artículo 14 de la Constitución Española. [...] Los órganos judiciales no pueden, por tanto, ignorar la dimensión constitucional de la cuestión ante ellos suscitada y limitarse a valorar, para excluir la violación del artículo 14 de la Constitución Española, si la diferencia de trato en relación con el disfrute del derecho [...] tiene en abstracto una justificación objetiva y razonable, sino que han de efectuar su análisis atendiendo a las circunstancias concurrentes, y sobre todo, a la trascendencia constitucional de este derecho de acuerdo con los intereses y valores familiares a que el mismo responde [...]. En definitiva, la resolución impugnada no acoge una interpretación viable de la norma aplicable que aseguraría a los hijos extramatrimoniales una idéntica cobertura familiar a sus necesidades, ocasionando una discriminación indirecta por razón de filiación [...]. Por consiguiente, la condición extramatrimonial no podría aceptarse como causa de desigualdad de trato dado que sería expresión de una minusvaloración a la que la Constitución quiere poner barrera, pues es notoria la posición de desventaja y, en esencia, de desigualdad sustancial que históricamente han conllevado las relaciones extramatrimoniales frente a las matrimoniales, así como los efectos desfavorables para los hijos nacidos en aquéllas ${ }^{51}$.

administrativas y del orden social. Esta normativa ha traspuesto las directivas de la Unión Europea contra posibles discriminaciones indirectas y sobre la protección jurídica a los particulares (Directiva 2000/43/CE, de 29 de junio, relativa a la aplicación del principio de igualdad de trato de las personas independientemente de su origen racial o étnico, y la Directiva 2000/78/CE, de 27 de noviembre, relativa al establecimiento de un marco general para la igualdad de trato en el empleo y la ocupación).

La STJUE (Sala Tercera) de 18 de enero de 2018, en el caso Carlos Enrique Ruiz Conejero contra Ferroser Servicios Auxiliares, S.A. y Ministerio Fiscal, estima la discriminación indirecta por razón de discapacidad de un trabajador.

51 Posteriormente, el TS ha extendido la interpretación defendida por el TC en relación con el incremento de la indemnización especial, al acrecimiento de la pensión de orfandad, al entender que ambos supuestos tienen el mismo régimen jurídico y la misma finalidad (SSTS [Sala Cuarta] de 9 de junio de 2008 y de 24 de septiembre de 2008). 
En consecuencia, una «norma aparentemente» neutra, como la disposición transitoria octava que como derecho transitorio remite a una normativa

La Ley 40/2007, de 4 de diciembre, de medidas en materia de Seguridad Social, señala como uno de sus objetivos el propósito de modernización del sistema al abordar las situaciones creadas por las nuevas realidades familiares y extiende el reconocimiento de la pensión de viudedad también a las parejas de hecho que cumplan los requisitos legalmente exigidos, y el derecho a la pensión de orfandad a cada uno de los hijos del causante cualquiera que sea la naturaleza de su filiación (arts. 174 y 175 LGSS).

Seguidamente, la STS (Sala Cuarta) de 28 de junio de 2013 ha estimado la existencia de una discriminación indirecta por razón de filiación en la pensión de orfandad, respecto a aquellos hijos no matrimoniales cuyos progenitores no constituyan parejas de hecho, o de quienes siéndolo de facto no se hayan constituido legalmente (es el caso de autos, en que la convivencia estable no fue acompañada de inscripción en el correspondiente registro de parejas de hecho). Esta discriminación existe porque «en ambas situaciones persiste la situación de necesidad que subyace como fundamento del mecanismo de acrecimiento de la pensión de orfandad y con el que se evita el impacto negativo que otra interpretación tiene en la realidad familiar y en la cobertura de las necesidades de los hijos extramatrimoniales. Asimismo, con tal conclusión se respeta más cumplidamente el decreto constitucional de protección integral de los hijos, con independencia de su filiación (art. $39 \mathrm{CE}$ ) y se acata el propio mandato legal de otorgamiento de la pensión en real régimen de igualdad, con independencia de la naturaleza de la filiación (art. 175.1 LGSS). Por último, se atiende a la consideración de que el incremento de las pensiones de orfandad resulta ser así una renta social sustitutiva de aquella prestación que falta en la unidad familiar cuando no se ha reconocido en la misma el derecho a una pensión de viudedad».

Esta situación de posible discriminación indirecta ha sido superada con la aprobación de la Ley de Seguridad Social de 30 de octubre de 2015, que recoge en su art. 224 que «tendrán derecho a la pensión de orfandad, en régimen de igualdad, cada uno de los hijos del causante, cualquiera que sea la naturaleza de su filiación».

En un sentido similar y, de conformidad con la doctrina constitucional, la Sala de lo Contencioso-Administrativo del TSJ de Castilla y León ha planteado por Auto de 25 de junio de 2015 una cuestión de inconstitucionalidad del art. 38.4 in fine de la Ley de Clases Pasivas del Estado que establece los requisitos legalmente exigidos para ser considerada pareja de hecho a efectos de la pensión de viudedad. El TSJ de Castilla y León entiende que la exigencia de requisitos agravados de convivencia y antigüedad para la constitución de la pareja de hecho respecto del matrimonio, a efectos de lucrar la pensión de viudedad, puede ser vulneradora de los arts. 14 y 39 CE cuando la pareja tiene hijos comunes dependientes, en cuanto es susceptible de producir una discriminación indirecta por razón de filiación. Esa discriminación indirecta se produce porque en el régimen de clases pasivas no resulta posible en ningún caso a los hijos acrecer la pensión de orfandad con el importe de la pensión de viudedad, en los casos de orfandad absoluta. Sin embargo, el ATC 11/2016, de 19 de enero, ha inadmitido a trámite la presente cuestión de inconstitucionalidad por falta de «conexión directa o nexo de subordinación entre la cuestión de inconstitucionalidad planteada y la debatida en el proceso del que trae causa». 
que otorga un trato diferente por razón de filiación legítima, natural e ilegítima, puede producir una discriminación indirecta prohibida por el art. 14 de nuestra Constitución.

\section{EL CRITERIO DEL TRIBUNAL EUROPEO DE DERECHOS HUMANOS SOBRE LA FIJACIÓN DE UNA «FECHA DE CORTE»}

El Tribunal Europeo de Derechos Humanos (TEDH) ha tenido la oportunidad de manifestarse respecto al diferente tratamiento en los derechos sucesorios de los hijos según la filiación legítima o no legítima, y la fecha de corte para la aplicación de las leyes que incluyen el principio de igualdad por razón de la filiación y sus efectos respecto a la sucesión hereditaria ${ }^{52}$. Si bien, y al contrario que en España, algunas de las sentencias recaídas en esta materia se refieren a la herencia de la madre.

En primer lugar, y respecto a Bélgica y Francia, el TEDH se ha pronunciado sobre el trato diferente que estos ordenamientos conceden a los hijos según su filiación en los derechos sucesorios de sus padres o ascendientes; $y$ ha analizado si ese diferente tratamiento es justificado, en cuyo caso no existiría vulneración del Convenio relativo a la protección de los derechos humanos y de las libertades fundamentales, firmado en Roma el 4 de noviembre de 1950 (Convenio), o, por el contrario, si el trato diferente «carece de una justificación objetiva y razonable, esto es, si no persigue un legítimo objetivo o si no existe una relación razonable de proporcionalidad entre los medios empleados y el objetivo perseguido", de modo que se produciría una violación del Convenio, en concreto del art. 14 (principio de igualdad y no discriminación) en relación con el art. 8 (respeto a la vida familiar), y de ambos en relación con el art. 1 del Protocolo núm. 1 (respeto a la propiedad privada y derechos patrimoniales).

Posteriormente, el Tribunal Europeo se ha manifestado sobre la fecha de corte, introducida como derecho transitorio en las legislaciones de Bélgica, Francia y Alemania, para la aplicación de la normativa que reconoce la igualdad y la no discriminación por razón de filiación a los efectos sucesorios.

En la Sentencia del Pleno Marckx contra Bélgica de 13 de junio de 1979, el Tribunal Europeo se pronuncia por vez primera en este tema. Los hechos: una madre soltera da a luz a una niña el 16 de octubre de 1973. La madre ini-

52 El Convenio europeo sobre el estatuto jurídico de los hijos nacidos fuera del matrimonio, firmado en Estrasburgo, el 15 de octubre de 1975, carece de mayor repercusión al haber sido ratificado solo por Austria, Dinamarca, Grecia, Irlanda, Luxemburgo, Portugal, el Reino Unido y Suecia. 
cia el expediente para determinar su maternidad, comunicando el nacimiento al encargado del registro. El 29 de octubre de 1973 reconoce a su hija, y se transforma automáticamente en su tutora. El 30 de octubre de 1974, la madre la adopta. La recurrente, actuando en su propio nombre y en representación de su hija menor, denuncia la discriminación contenida en el Código Civil belga respecto a la determinación de la filiación materna natural, a las relaciones de parentesco de la hija natural con los parientes de la madre, y, por último, a los derechos patrimoniales y sucesorios tanto de la hija como de la madre naturales.

En efecto, la legislación de Bélgica discriminaba a las madres solteras respecto de las casadas. La soltera tenía que iniciar un expediente para establecer legalmente su maternidad. Pero la determinación de la maternidad no determinaba la filiación materna. Para determinar la filiación, la madre tenía que adoptar a la hija. Pero la adopción impedía a la madre dejarle sus bienes mortis causa. Además, en ningún caso, se creaba una relación de parentesco más allá de la materno-filial: la hija natural no se convertía en nieta de la madre de su madre, ni en sobrina de la hermana de su madre, ni tenía derechos sucesorios en la herencia de la madre y de la hermana de su madre. De acuerdo con la legislación belga, el hijo ilegítimo carecía de la cualidad de heredero en la sucesión de sus progenitores, se le consideraba sucesor irregular, y sus derechos sucesorios eran menores en cantidad que los de los hijos legítimos (arts. 756 a 766 Code civil belga).

El TEDH estima la vulneración del art. 14 del Convenio, en relación con el art. 8, por dos razones fundamentales: las restricciones de la capacidad de la hija ilegítima para recibir bienes de su madre, y la ausencia total de derechos hereditarios en la sucesión intestada de los parientes de la madre (en el caso concreto de la abuela). El TEDH no encuentra ninguna justificación objetiva y razonable para las diferencias de tratamiento jurídico. Admite que en ciertos casos la tranquilidad de la familia del progenitor puede verse perturbada por la aparición de un hijo ilegítimo que se incluya en la familia en igualdad de condiciones que los hijos matrimoniales, pero ello no justifica el hecho de que el hijo ilegítimo se vea privado de sus derechos fundamentales.

Entonces, el ordenamiento belga introdujo la igualdad ante la ley por razón de la filiación mediante Ley de 31 de marzo de 1987, que modificó diversas disposiciones legales relativas a la filiación y a la sucesión mortis causa. El art. 72 de esta ley derogó los art. 756 a 766 del Code civil relativos a los «derechos de los hijos naturales sobre los bienes de su padre o madre y de la sucesión a los hijos naturales muertos sin descendencia». El art. 107, el primero del capítulo 13 dedicado a las disposiciones transitorias de la ley, consideró aplicable la ley a todos los hijos aunque hubiesen nacido con anterioridad, siempre que siguieran vivos; pero introdujo una fecha de 
corte para la concesión de los derechos hereditarios: la entrada en vigor de la ley (6 de junio de 1987), de modo que no otorgaba derechos a los hijos ilegitimos en las sucesiones que se hubieran abierto con anterioridad a su entrada en vigor (mais sans qu'il puisse en résulter aucun droit dans les successions ouvertes auparavant).

La fijación de esta fecha de corte para la sucesión ha sido analizada en la Sentencia Vermeire contra Bélgica de 29 de noviembre de 1991. El TEDH resuelve la posible discriminación de una nieta, hija natural de un hijo fallecido soltero, en las herencias intestadas de su abuelo (fallecido en 1980) y de su abuela (fallecida en 1975), contra los dos hijos de otro hijo. El tercer hijo había fallecido soltero sin descendencia. Los tribunales belgas, de acuerdo con la fecha de corte establecida en la ley de 1987, habían mantenido la diferencia de trato por razón de filiación en los derechos sucesorios, y aplicado la redacción vigente del Código Civil en el momento del fallecimiento del abuelo y de la abuela, por lo que habían fallado que la nieta, hija natural de un hijo legítimo premuerto, carecía de derechos sucesorios en las dos sucesiones.

El Tribunal Europeo distingue entre la sucesión del abuelo por haber fallecido en 1980, con posterioridad al asunto Marckx contra Bélgica, y la sucesión de la abuela fallecida en 1975, aunque su sucesión había quedado indivisa hasta el fallecimiento de su esposo. Concede a la nieta derechos en la sucesión de su abuelo, justificando su decisión en que el fallecimiento se produjo después del asunto Marckx, y, por tanto, "con las mismas quejas y reclamaciones que aquellas que fueron acogidas en la sentencia Marckx». Pero no le reconoce derechos en la herencia de la abuela. Es de notar que el TEDH no respeta la fecha de corte - 6 de junio de 1987- establecida en la ley de 1987, sino que establece otra fecha de corte: la de la Sentencia Marckx de 13 de junio de 1979.

Francia había reformado el Code civil, mediante la Ley de 3 de enero de 1972, y equiparado a los hijos naturales con los legítimos, pero mantenía la diferencia de trato establecida en la redacción originaria del Code civil respecto a los hijos adulterinos - e incestuosos-, con efectos distintos en orden a la sucesión del padre y de la madre (arts. 757 a 762). En efecto, el ordenamiento francés discriminaba a los hijos adulterinos respecto a los hijos legítimos en las herencias de sus progenitores, lo que motiva la denuncia de los nacionales franceses ante el TEDH.

La sentencia Mazurek contra Francia de 1 de febrero de 2000 resolvió sobre la diferencia de trato del hijo adulterino en la herencia de su madre. En este supuesto, la causante había fallecido en 1990, dejando dos hijos: un hijo natural nacido en 1936 y legitimado por el matrimonio de sus padres en 1937, y el demandante, hijo adulterino, nacido en 1942, cuando la madre estaba casada, aunque separada de hecho (se divorció en 1944). El hijo 
adulterino demanda la mitad de la herencia de su madre, pero únicamente obtiene un cuarto de la herencia, de acuerdo con el art. 760 Code civil francés que reconocía al hijo adulterino la mitad de la parte que le hubiera correspondido si hubiera sido hijo legítimo.

El hijo adulterino denuncia al TEDH la discriminación, alegando que en su caso la protección de la familia legítima no justifica la discriminación, pues el otro hijo era natural legitimado por posterior matrimonio. En ambos casos, los dos eran hijos concebidos fuera del matrimonio.

El TEDH considera que el art. 760 del Code civil vulnera el principio de igualdad del art. 14 del Convenio, que la diferencia de trato es discriminatoria, pues carece de justificación objetiva y razonable, y que la aplicación de la norma francesa determinó que el demandante, debido a su condición de hijo adulterino, se encontrara penalizado en el reparto del caudal hereditario, por lo que estima vulnerado el art. 1 del Protocolo núm. 1 en lo que concierne a los derechos hereditarios en relación con el art. 14 del Convenio, y no entra a analizar la posible vulneración del art. 14 combinado con el art. 8.

Este tema se reitera en la Sentencia Merger y Cros contra Francia de 22 de diciembre de 2004 (la demanda se había presentado ante el Tribunal el 3 de noviembre de 2000). El causante había fallecido en 1986 dejando esposa, cuatro hijos legítimos y una hija adulterina llamada Hermance Merger, nacida en 1968 de una convivencia iniciada por el causante en 1965 con Clémentine Cross, una viuda que ya tenía otra hija. El causante había reconocido a su hija adulterina en 1973. En el testamento, el causante iguala a los cinco hijos, y además deja la porción de libre disposición a la hija adulterina.

Los tribunales franceses aplican la legislación conforme a la Ley de 3 de enero de 1972 y, por lo tanto, distinguiendo entre los hijos legítimos y naturales, por un lado, y los hijos adulterinos, por otro. El Tribunal de Gran Instancia de París falla en 1992 a favor de los hijos matrimoniales y de la esposa, y fija los derechos de la hija adulterina en el $10 \%$ del activo neto de la herencia (la mitad de lo que le hubiera correspondido de haber sido hija legítima). El Tribunal de Casación no admite el recurso de casación el 3 de mayo de 2000.

El TEDH no percibe ningún elemento que permita apartarse de la jurisprudencia sentada en la Sentencia Mazurek contra Francia y, por ello, declara la vulneración del art. 1 del Protocolo núm. 1 en lo relativo a los derechos hereditarios en relación con el art. 14 del Convenio, con lo que no entra a analizar la posible vulneración del art. 14 combinado con el art. 8 .

A raíz de la Sentencia Mazurek, Francia reforma el Code civil mediante Ley de 3 de diciembre de 2001, igualando los derechos sucesorios de los hijos 
adulterinos a los legítimos y naturales (nuevo art. 735 Code civil) ${ }^{53}$. El art. 25 de la referida ley sobre su entrada en vigor fija como fecha de corte el día de la publicación de la ley en el Journal Officiel de la République Française, esto es, el 4 de diciembre de 2001. La fecha de corte se refiere a la partición (n'ayant pas donné lieu à partage avant cette date). De modo que la nueva ley será aplicable también a las sucesiones abiertas antes de esta fecha, siempre que no se hubiera realizado la partición de la herencia, y sin perjuicio de los acuerdos alcanzados entre las partes y de las decisiones judiciales irrevocables (art. 25-II.2. ${ }^{\circ}$ ).

Esta fecha de corte establecida en el art. 25-II.2 de la Ley de 2001 es también denunciada ante el TEDH, que resuelve en la Sentencia Fabris contra Francia de 7 de febrero de 2013. En el supuesto de hecho, la causante había fallecido en julio de 1994, con dos hijos matrimoniales (nacidos en 1923 y 1941) y un hijo adulterino, nacido en 1943, que obtuvo declaración de su filiación materna por Sentencia del Tribunal de Primera Instancia de Montpellier de 24 de noviembre de 1983. Con anterioridad, el 24 de enero de 1970, la causante y su marido habían realizado a favor de los dos hijos matrimoniales una donación-partición de sus bienes, con reserva de usufructo y una acción revocatoria para garantizar los términos y condiciones de la donación. En la firma, los dos esposos declararon no tener más hijos. Tras el fallecimiento de la causante en 1994, los hijos matrimoniales ofrecen al hijo adulterino el pago en metálico de la porción de la herencia que le correspondería en su cualidad de hijo no legítimo según el art. 760 Code civil (redacción de 1972).

El hijo adulterino interpone demanda en reclamación de sus derechos que es estimada por el Tribunal de Primera Instancia de Béziers, en aplicación de la Ley de 2001, recién aprobada, a favor de la igualdad de los hijos ante la ley. Considera de aplicación la disposición transitoria, pues entiende que no se había producido todavía la partición de la herencia (art. 25-II.2. de la ley). Sin embargo, las sentencias de apelación y casación desestiman la demanda. La Sentencia del Tribunal de Casación de 14 de noviembre de 2007 entiende que la sucesión no estaba abierta el 4 de diciembre de 2001, pues se había realizado un reparto sucesorio tras el fallecimiento de la causante en julio de 1994, como consecuencia de la donación-partición de 1970. Por lo que aplica la ley vigente en el momento del fallecimiento de la causante que diferenciaba entre hijos legítimos y naturales e hijos adulterinos.

El demandante denuncia ante el TEDH la discriminación, en cuanto que hijo adulterino respecto a los derechos sucesorios, con vulneración del art. 14 en relación con el art. 1 del Protocolo núm. 1, alegando que se produce

53 Posteriormente, la Ordonnance de reforma de la filiación de 4 de julio de 2005 suprimió del Code civil las expresiones hijo legitimo, hijo natural e hijo adulterino. 
una discriminación permanente que perpetúa los efectos de la Ley de 1972, derogada en 2001, y que había sido objeto de un pronunciamiento del TEDH desfavorable para Francia.

El Gobierno francés defiende la necesidad de fijar una fecha de corte, en atención al principio de seguridad jurídica, que excluya la aplicación de la ley a las sucesiones en las que ya se haya producido el reparto de los bienes. En el caso examinado, lo fija producido en 1970 con la donación partición.

El TEDH considera que asegurar la estabilidad de las sucesiones completadas constituye un fin legítimo susceptible de justificar una diferencia de trato entre las distintas clases de hijos, pero que no concurre una razonable relación de proporcionalidad entre los medios empleados y el fin legítimo perseguido. Además, entiende que tampoco estaba tan completada esa sucesión, pues tras la apertura de la sucesión un hijo legítimo preterido puede pedir la reducción de la donación partición realizada en vida por los padres. Por tanto, se deriva que la sucesión no está completada mientras se pueda reclamar algún derecho hereditario. El TEDH señala que la única razón por la que el demandante ha visto rechazado el derecho a solicitar la reducción de la donación-partición realizada por su madre es el carácter adulterino de su filiación y, en consecuencia, en este aspecto, se asemeja a los asuntos Mazurek y Merger y Cros. El fallo por unanimidad declara vulnerado el art. 14 del Convenio en relación con el art. 1 del Protocolo núm. 1, sin necesidad de entrar a examinar separadamente la violación del art. 14 combinado con el art. 8 .

Alemania resulta ser el tercer país que ha visto cuestionar ante el TEDH la fecha de corte contenida en el derecho transitorio de la legislación que introdujo el principio de igualdad y la no discriminación por razón de filiación respecto a los derechos sucesorios de los hijos ilegítimos.

En efecto, en la República Federal Alemana (RFA), la Ley Fundamental de Bonn de mayo de 1949 había incluido en el art. 6.5 la obligación de la legislación de asegurar a los hijos nacidos fuera del matrimonio las mismas condiciones que para los hijos nacidos dentro del matrimonio en lo que respecta a su desarrollo físico y espiritual y a su posición social. En cumplimiento este mandato, se dotó por Ley de 19 de agosto de 1969 de estatus jurídico a los hijos nacidos fuera del matrimonio. En las disposiciones transitorias de esta ley recogidas en el art. 12, el $\$ 10$ determinó en la sucesión legal de los padres la total exclusión de los hijos habidos fuera del matrimonio que hubieran nacido con anterioridad al 1 de julio de 1949 (fecha fijada en relación con la Ley Fundamental) (art. 12.10, párr. 2, primera frase) $)^{54}$. Mientras que

54 El Tribunal Constitucional alemán en las sentencias de 8 de diciembre de 1976 y de 3 de julio de 1996 ha analizado la conformidad del establecimiento de una fecha 
a los hijos nacidos con posterioridad a esta fecha la ley les concedía derecho a una compensación económica equivalente a su parte en la sucesión que debía ser satisfecha por los herederos del causante. La Ley de 16 de diciembre de 1997 sobre la asimilación de los hijos nacidos fuera del matrimonio en materia de sucesión y la Ley de 9 de abril de 2002 sobre la mejora de los derechos de los menores han ratificado la fecha de corte prevista en el art. 12.10, párr. 2, primera frase de la ley de 1969.

En la Sentencia Brauer contra Alemania de 28 de mayo de 2009, el TEDH ha tenido ocasión de analizar la validez de la fijación de la fecha de corte, en un supuesto complejo por la conexión con la legislación de la República Democrática Alemana (RDA).

Interpone la denuncia una hija extramatrimonial, nacida en 1948 y reconocida al poco de nacer que había vivido en la RDA. El padre había vivido y fallecido en la RFA. La fecha de fallecimiento del causante era incierta, pudiendo situarla entre el 30 de junio y el 3 de julio de 1998. La hija reclama sus derechos sucesorios, pues la regulación de la antigua RDA había proclamado la igualdad de los hijos con independencia de su filiación.

Sin embargo, a la sucesión del causante se le aplica la ley del lugar de residencia del de cuius en el momento de la reunificación alemana (el 3 de octubre de 1990), en el caso la RFA. En consecuencia, los tribunales alemanes (incluido el Tribunal Constitucional, que inadmitió el recurso el 20 noviembre 2003), con base en la protección de la confianza del de cuius, niegan todo derecho a la hija no matrimonial, pues, aunque en el momento del fallecimiento del causante existía la igualdad legal por razón de filiación, se le aplica la fecha de corte establecida en el derecho transitorio (art. 12.10, párr. 2, primera frase), por la que se beneficiaban de la igualdad los hijos no matrimoniales nacidos después del 1 de julio de 1949, pero no los nacidos antes de esta fecha.

La demandante denuncia la disposición transitoria (art. 12.10, párr. 2, primera frase, de la Ley sobre el estatus jurídico de los hijos nacidos fuera del matrimonio de 1969), ante el TEDH, alegando el principio de igualdad y no discriminación del art. 14 del Convenio. El fallo de la sentencia reconoce que la finalidad perseguida por la fijación de una fecha de corte, a saber, garantizar la seguridad jurídica y la protección del de cuius y de su familia, puede ser considerada como legítima. Pero debe ceder en una interpretación dinámica del Convenio ante el imperativo de la igualdad de trato entre hijos

de corte (art. 12.10, párr. 2, primera frase) con el art. 6.5 de la Ley Fundamental, y justificado por la dificultad práctica y procesal para la prueba de la filiación y en la seguridad jurídica o "confianza» del de cuius y de su familia en la perennidad de esa excepción. 
matrimoniales y no matrimoniales. El TEDH estima la vulneración del art. 14 en relación con el art. 8 del Convenio.

Como resultado de la Sentencia Brauer contra Alemania, el Parlamento alemán aprueba otra Ley de 12 de abril de 2011 sobre la igualdad por razón de filiación en los derechos sucesorios, en la que mantiene la fecha de corte respecto a los hijos que nacieron antes del 1 de julio de 1949, pero la combina con otra fecha de corte fijada en la fecha de la sentencia Brauer el 28 de mayo de 2009 respecto al fallecimiento del causante; por lo que al establecer la concurrencia de los dos elementos (fechas de corte) reduce el ámbito de la excepción al principio de igualdad y no discriminación por razón de filiación en los derechos sucesorios.

Sin embargo, el establecimiento de estas fechas de corte ha vuelto a ser declarado contrario al Convenio en las sentencias Mitzinger contra Alemania de 9 de febrero de 2017 y Wolter y Sarfert contra Alemania de 23 de marzo de 2017.

En la Sentencia Mitzinger contra Alemania de 9 de febrero de 2017, el causante había fallecido el 4 de enero de 2009 , dejando esposa y una hija natural, la demandante, nacida antes del 1 de julio de 1949 y reconocida en el año 1951. El 14 de enero de 2009, la demandante solicita, junto con sus derechos hereditarios, el derecho a administrar las propiedades de su padre con la finalidad de proteger la herencia, dada la incapacidad de la viuda debida a una grave enfermedad.

Los tribunales de instancia rechazan las pretensiones de la demandante, con base en que la fecha de corte de haber nacido después del 1 de julio de 1949 había sido aceptada por los pronunciamientos del Tribunal Constitucional que la habían encontrado conforme a la Ley Fundamental. Contra esta sentencia, la demandante ejercita recurso constitucional ante el Tribunal Constitucional, denunciando una discriminación como resultado de la aplicación de la mencionada disposición, el cual fue inadmitido a trámite.

Entonces, la demandante acude al TEDH denunciando violación del art. 14 en conexión con el art. 8. Esta vulneración es confirmada por el Tribunal reiterando la fundamentación contenida en el asunto Brauer, pero da un paso más, al estimar que no existe una relación razonable de proporcionalidad entre los medios empleados y el objetivo perseguido.

La Sentencia Wolter y Sarfert contra Alemania de 23 de marzo de 2017 acumula dos procedimientos ${ }^{55}$, en la que ambos demandantes son hijos

55 El Tribunal decide, considerando la similitud de los casos y los antecedentes legales, que ambas demandas pueden ser acumuladas en virtud del art. 42.1 del Reglamento del TEDH. 
nacidos antes del 1 de julio de 1949 fuera del matrimonio, sus causantes han fallecido antes del 28 de mayo de 2009 y sufren discriminación respecto a los hijos matrimoniales en la sucesión de sus respectivos padres ${ }^{56}$.

El TEDH reitera la argumentación expuesta de la sentencia Mitzinger; sostiene que la diferencia de trato de los hijos no matrimoniales según la fecha de nacimiento tiene como objetivo preservar la seguridad jurídica y la protección de la voluntad del fallecido y los derechos de su familia, y que la introducción de una fecha de corte para aplicar una nueva regulación que elimina la discriminación, podría considerarse un medio adecuado de alcanzar claridad y preservar la seguridad jurídica. Sin embargo, admitiendo que pueden ser objetivos legítimos, el TEDH considera que no existe una relación razonable de proporcionalidad entre los medios empleados y el objetivo perseguido, pues el trato diferente se basa en el carácter no matrimonial de los hijos. De modo que concluye que la diferencia de trato, basada en la condición de los demandantes de hijos nacidos fuera del matrimonio que les excluye de cualquier derecho a la herencia, resulta contraria a las garantías del art. 14 del Convenio en relación con el art. 1 del Protocolo núm. 1.

56 El primer demandante, nacido en 1943, es hijo natural del causante, quien reconoció su paternidad meses después de su nacimiento y falleció en 2007 . Entonces, el hijo solicita un certificado de sucesión que reconocía el derecho al total de la herencia. Los tribunales alemanes anularon el certificado, por la aplicación del art. 12.10.2 de la ley de 1969, debido a que el hijo no matrimonial nacido antes del 1 de julio de 1949 carece de derechos en la herencia de su padre.

Además, el Tribunal de apelación, por decisión de 11 de octubre de 2010, afirma que la sentencia Brauer no provoca un cambio de postura dado que los tribunales alemanes no están obligados por las decisiones de ese tribunal y que la interpretación de la legislación interna a la luz del Convenio Europeo está restringida cuando la legislación interna es clara, no abierta a otras interpretaciones. El Tribunal Constitucional alemán desestima el recurso del demandante, confirmando la conformidad del art. 12.10.2 de la ley de 1969 con la Ley Fundamental, en una decisión fechada el 18 de marzo de 2013.

El segundo demandante nacido en 1940 en la RDA es hijo natural del causante fallecido el 26 de junio de 2006, bajo testamento en el que instituía a su hija matrimonial como única heredera. En 2009, tras el asunto Brauer, el demandante solicita sus derechos legitimarios ante la jurisdicción nacional. Los tribunales alemanes le niegan derechos en la sucesión de su padre por aplicación del art. 12.10.2 de la ley de 1969, afirmando que la diferencia de trato era debida a motivos legítimos. Asimismo, el Tribunal Constitucional alemán desestima el recurso por decisión fechada el mismo día: 18 de marzo de 2013. 
En suma, el Tribunal Europeo de Derechos Humanos considera que las legislaciones nacionales que establecen fechas de corte de derecho transitorio para la aplicación del principio de igualdad por razón de filiación o nacimiento respecto a los derechos hereditarios de los hijos vulneran el principio de igualdad y son contrarias al Convenio Europeo de Derechos Humanos.

\section{Bibliografía}

Aguilar Benítez de Lugo, M. y Aguilar Grieder, H. (2005). Orden público y sucesiones (II). Boletín del Ministerio de Justicia, 59, 1123-1147.

Albaladejo García, M. (1988). La Ley que rija al morir el causante es la que regula la sucesión en que incida una adopción. Anuario de Derecho Civil, 41, 441-468. (1990). Comentario al artículo 657 del Código civil. En M. Albaladejo García. Comentarios al Código civil y Compilaciones forales, t. IX, vol. 1-A (pp. 1-3). Madrid: Edersa.

Alemany Verdaguer, S. (1974). Estudios sobre la filiación ilegitima en el derecho español. Barcelona: Boch.

Alonso García, E. (1982). ¿Es retroactiva la Constitución? Homenaje a José Antonio García-Trevijano Fos (pp. 1-18). Madrid: Colegio Universitario de Estudios Financieros.

Álvarez González, S. (2015). ¿ Orden público europeo versus orden público internacional de cada estado? En La gobernanza del interés público global. XXV Jornadas de la Asociación Española de Profesores de Derecho Internacional y Relaciones Internacionales. Barcelona, 19-20 de septiembre de 2013 (pp. 146-181). Madrid: Tecnos.

- (2016). Sobre la discriminación sucesoria por razón de sexo en el Derecho iraní y el orden público español (Comentario a la Resolución de la DGRN de 20 de julio de 2016). Bitácora Millennium DIPr: Derecho Internacional Privado, 4, $1-16$.

Arroyo i Amayuelas, E. y Bondia García, D. (2004). ¿Interpretación de testamento contraria a los derechos humanos? El caso Pla \& Puncernau vs. Andorra (STEDH, 13 de julio de 2004). Derecho Privado y Constitución, 18, 7-88.

Barber Cárcamo, R. (2013). La filiación en España. Una visión crítica. Pamplona: Aranzadi.

Barrio Gallardo, A. (2016). Libertad de testar y principio de no discriminación: ¿una nueva modalidad de disposiciones sucesorias con causa ilícita? Revista Aranzadi de Derecho Patrimonial, 41, 201-219.

Bercovitz Rodríguez-Cano, R. (2010). Un buen voto particular. Aranzadi Civil: Revista Doctrinal, 4, 11-15.

Blázquez Rodríguez, I. (2009). El Derecho sucesorio islámico: principios informadores y excepción de orden público internacional. Revista española de Derecho Internacional, 61, 441-453. 
Carrascosa González, J. (2008). Orden público internacional y externalidades negativas. Boletín del Ministerio de Justicia, 62, 2351-2378.

Cobas Cobiella, E. (2008). Principio de Igualdad versus Principio de Seguridad Jurídica. Algunas notas sobre la Sentencia del Tribunal Supremo de 31 de julio de 2007 (RJ 2007, 6258). Revista de Derecho Patrimonial, 21, 431-442.

Corriente Córdoba, J. A. (1975). La excepción de orden público en el Derecho internacional Privado Español. Anuario Español de Derecho Internacional, 2, 125168.

De la Cámara Álvarez, M. (1984). Capítulo IX. Comentario a las disposiciones transitorias de la Ley de 13 de mayo 1981, relativas a la filiación. En M. Albaladejo García (dir.) Comentarios al Código Civil y Compilaciones Forales, t. III (pp. 960988). Madrid: Edersa

De Pablo Contreras, P. (1987). Preterición, Derecho intertemporal y Constitución Española. Comentario a la Sentencia del Tribunal Supremo de 10 de febrero de 1986. Anuario de Derecho Civil, 2, 701-713.

Díez-Picazo Giménez, G. (2014). Dos recientes sentencias del Tribunal Constitucional acerca del derecho de sucesiones. En A. Domínguez Luelmo y M. a P. García Rubio (dirs.). Estudios de derecho de sucesiones: "Liber amicoru" Teodora F. Torres García (pp. 347-370). Madrid: Wolters Kluwer.

Durán Rivacoba, R. y Carbajo González, J. (2012). Las desigualdades jurídicas entre las filiaciones adoptiva y por naturaleza. Derecho Privado y Constitución, 26, 9-63.

Espejo Lerdo de Tejada, M. (1997). Reforma constitucional de la filiación, preterición y problemas de derecho transitorio (A propósito de la STS de 17 de marzo de 1995). Anuario de Derecho Civil, 1, 377-412.

— (2006). Efectos de la determinación de la filiación no matrimonial sobre la sucesión de progenitor fallecido antes de la Constitución de 1978. Comentario de la STS de 17 de marzo de 2005. Revista de Derecho Patrimonial, 16, 381-397.

— (2011). Interpretación del testamento y principio constitucional de igualdad. Consideraciones acerca de la STC de 27 de abril de 2010. Derecho Privado y Constitución, 25, 229-260.

— (2014). La sustitución fideicomisaria y la aplicación imperativa del principio constitucional de igualdad: comentario a la STS de 1 de marzo de 2013. Revista de Derecho Patrimonial, 35, 449-471.

- (2016). Sentencia del Tribunal Constitucional 9/2010, de 27 de abril de 2010 (Testador y principios constitucionales). En Vázquez de Castro, L. M y Escribano Tortajada, P. (Coord.). Comentarios a las Sentencias del Tribunal Constitucional en materia civil (pp. 621-663). Valencia: Tirant Lo Blanch.

(2018). La igualdad ante la ley de los hijos con independencia de su filiación en el derecho de sucesiones. Revista jurídica del Notariado, Extra-1, 415-446.

Fajardo Fernández, J. (2017). Igualdad de los hijos en sucesiones abiertas (pero no agotadas) antes de la entrada en vigor de la Constitución. Aranzadi civil-mercantil, 4, 61-76. 
Femenía López, P. J. (2008). Los derechos sucesorios de los hijos no matrimoniales en sucesiones abiertas con anterioridad a la Constitución de 1978. Comentario a la STS de 31 de julio de 2007. Derecho Privado y Constitución, 22, 131-167.

Fernández de Frutos, M. (2011). Prohibición de discriminación por razón de nacimiento e interpretación de las disposiciones testamentarias por los órganos judiciales. Revista Juridica de Catalunya, 110, 119-132.

García Presas, I. (2011). El Derecho de Familia en España desde las últimas reformas del Código Civil. En Actas del I Congreso Ibero-Asiático de Hispanistas Siglo de Oro e Hispanismo general (pp. 237-265). Navarra: GRISO.

García-Bernardo Landeta, A. (2002). Los derechos sucesorios en las adopciones. Revista jurídica del Notariado, 43, 19-70.

González Campos, J y Fernández Rozas, J. C. (1995). Comentario al artículo 12.3 del Código Civil. En M. Albaladejo García y S. Díaz Alabart (dirs.) Comentarios al Código civil y Compilaciones forales, t. I, vol. II (pp. 894-826). Madrid: Edersa.

Herrero Oviedo, M. (2012). El testamento, la filiación adoptiva y la aplicación inter privatos de los Derechos Fundamentales. Indret: Revista para el Análisis del Derecho, 2, 1-35.

Hornero Méndez, C. (2016). Si el señorito falleció antes de la Constitución de 1978, el hijo de la criada no será heredero: filiación no matrimonial y sucesión abierta (y consumada). Revista Aranzadi de Derecho Patrimonial, 40, 319-333.

Imaz Zubiaur, L. (2014). Comentario a la Sentencia de 1 de marzo de 2013. La aplicación retroactiva del principio constitucional de igualdad respecto de relaciones jurídicas sucesorias no agotadas o pendientes de ejecución en el marco de una sustitución fideicomisaria. Cuadernos Civitas de Jurisprudencia Civil, 94 , 132-158.

Martín Pérez, J. A. (2011). Comentario al artículo 657 del Código civil. En A. Cañizares Laso, P. de Pablo Contreras, J. Orduña Moreno y R. Valpuesta Fernández (dirs.). Código civil comentado, vol. II (pp. 241-244). Pamplona: ThomsonReuters.

Martínez-Calcerrada Gómez, L. (2007). Sobre una supuesta discriminación post mortem de los hijos extramatrimoniales. A propósito de la Sentencia de la Sala $1^{\text {a }}$ del Tribunal Supremo de 31 de julio de 2007. La Ley, 6550, 1-3.

Miquel González, J. M. (1984). Comentario a la Disposición transitoria octava de la Ley 11/1981, de 13 de mayo. En Comentarios a las Reformas del Derecho de Familia, vol. II (pp. 1992-2001). Madrid: Tecnos.

(1985). Preterición. Revocación del testamento. Declaración de heredero abintestato. Incongruencia. Necesidad de intervención del Ministerio Fiscal. Comentario a la Sentencia del Tribunal Supremo de 13 de julio de 1985. Cuadernos Civitas de Jurisprudencia Civil, 9, 2879-2893.

— (1986). Derogación de preceptos del Código Civil por la Constitución. Comentario a la Sentencia del Tribunal Supremo de 10 de febrero de 1986. Cuadernos Civitas de Jurisprudencia Civil, 10, 3435-3442. 
Moreno Sánchez-Moraleda, A. (2017). No inscripción en un registro español de una escritura de herencia por aplicación del orden público internacional del foro. Comentario de la Resolución de la Dirección General de Registros y Notariado núm. 8569/2016, de 20 de julio (RJ 2016, 4595). Revista Aranzadi de Derecho Patrimonial, 42, 355-370.

Oró Martínez, C. (2009). Orden público internacional y prohibiciones para suceder de la "mudawana". Fundamento y alcance de la excepción de orden público aplicada a la sucesión de un causante marroquí [a propósito de la SAP de Barcelona (Sección 4a) de 28 de octubre de 2008]. Dereito: Revista Xurídica da Universidade de Santiago de Compostela, 18, 287-304.

Pizarro Moreno, E. (2016). Constitución española y relaciones jurídicas no agotadas en la dinámica sucesoria. Revista de Derecho Patrimonial, 41, 373-385.

Polo Arévalo, E. M. a (2011). Igualdad y filiación. Estudio de la discriminación de los hijos por razón de nacimiento. Pamplona: Thomson-Reuters.

Rivero Hernández, F. (1995). Preterición de hijo extramatrimonial en sucesión abierta después de la Constitución y antes de la entrada en vigor de la Ley 11/1981. Comentario a la STS de 17 de marzo de 1995. Derecho Privado y Constitución, 6, 227-272.

Romero Coloma, A. M. (2011). Interpretación de testamento y comentario a la sentencia de 27 de abril de 2010. Revista Critica de Derecho Inmobiliario, 728, 3319-3334.

Rubio Garrido, T. (2013). Comentario al artículo 657 del Código civil. En R. Bercovitz Rodríguez-Cano (coord.). Comentarios al Código civil, t. IV (pp. 50155037). Valencia: Tirant lo Blanch.

Salas Carceller, A. (2007). La situación de los hijos ilegítimos en las sucesiones abiertas con anterioridad a la entrada en vigor de la Constitución. Repertorio de Jurisprudencia, 30, 467-472.

Sánchez-Rubio García, A. (1994). Derechos sucesorios de los hijos adoptivos en el Código Civil: (problemas de derecho transitorio). Barcelona: Bosch.

Seisdedos Muiño, A. (2008), El principio de igualdad ante la Ley en las sucesiones abiertas antes de la entrada en vigor de la Constitución (Comentario a la STS de 31 de julio de 2007). Revista de Derecho Privado, 92, 89-102.

Verdera Izquierdo, B. (2011). Discriminación por razón de nacimiento. Derechos sucesorios de los adoptados. Actualidad civil, 1, 1-12.

Viguri Perea, A. (2016). Sentencia del Tribunal Constitucional 177/2007, de 23 de julio (Paternidad y prueba biológica). En L. Martínez Vázquez de Castro (coord.). Comentarios a las Sentencias del Tribunal Constitucional en materia civil (pp. 823-863). Valencia: Tirant lo Blanch.

Viteri Zubia, I. (2017). Aplicación retroactiva del principio constitucional de igualdad o no discriminación a relaciones jurídicas sucesorias no agotadas o pendientes de ejecución por el acaecimiento de distintas vocaciones hereditarias y delaciones de la herencia. Comentario a la STS de 1 junio 2016 (RJ 2016, 2319). Cuadernos Civitas de Jurisprudencia Civil, 104, 15-31. 


\section{ANEXO. ÍNDICE DE SENTENCIAS Y RESOLUCIONES}

\section{Tribunal de Justicia de la Unión Europea}

Sentencia de 18 de enero de 2018, caso Ruiz Conejero (Asunto C-270/16).

\section{Tribunal Europeo de Derechos Humanos}

Sentencia de 13 de junio de 1979, caso Marckx contra Bélgica.

Sentencia de 29 de noviembre de 1991, caso Vermeire contra Bélgica.

Sentencia de 1 de febrero de 2000, caso Mazurek contra Francia.

Sentencia de 13 de julio de 2004, caso Pla y Puncernau contra Andorra.

Sentencia de 22 de diciembre de 2004, caso Merger y Cros contra Francia.

Sentencia de 28 de mayo de 2009, caso Brauer contra Alemania.

Sentencia de 7 de febrero de 2013, caso Fabris contra Francia.

Sentencia de 9 de febrero de 2017, caso Mitzinger contra Alemania.

Sentencia de 23 de marzo de 2017, caso Wolter y Sarfert contra Alemania.

\section{Tribunal Constitucional}

Sentencia 9/1981, de 31 de marzo (RTC 1981, 9).

Sentencia 10/1981, de 6 de abril (RTC 1981, 10).

Sentencia 17/1981, de 1 de junio (RTC 1981, 17).

Sentencia 43/1982, de 6 de julio (RTC 1982, 43).

Sentencia 80/1982, de 20 de diciembre (RTC 1982, 80).

Sentencia 6/1983, de 4 de febrero (RTC 1983, 6).

Sentencia 72/1984, de 14 de junio (RTC 1984, 72).

Sentencia 42/1986, de 10 de abril (RTC 1987, 42).

Sentencia 35/1987, de 18 de marzo (RTC 1987, 35).

Sentencia 99/1987, de 11 de junio (RTC 1987, 99).

Sentencia 155/1987, de 14 de octubre (RTC 1987, 155).

Auto 347/1988, de 16 de marzo (ECLI:ES:TC:1988:347A).

Sentencia 227/1988, de 29 de noviembre (RTC 1988, 227).

Sentencia 210/1990, de 20 de diciembre (RTC 1990, 210).

Auto 22/1992, de 27 de enero (ECLI:ES:TC:1992:22A).

Sentencia 182/1997, de 28 de octubre (RTC 1997, 182).

Sentencia 203/2000, de 24 de julio (RTC 2000, 203).

Sentencia 13/2001, de 29 de enero (RTC 2001, 13).

Sentencia 200/2001, de 4 de octubre (RTC 2001, 200).

Sentencia 253/2004, de 22 de diciembre (RTC 2004, 253).

Sentencia 154/2006, de 22 de mayo (RTC 2006, 154).

Sentencia 69/2007, de 16 de abril (RTC 2007, 69).

Sentencia 9/2010, de 27 de abril (RTC 2010, 9). 
Auto 11/2016, de 19 de enero (RTC 2016, 11 AUTO).

Sentencia 105/2017, de 18 de septiembre (RTC 2017, 105).

\section{Tribunal Supremo. Sala Primera}

Sentencia de 16 de enero de 1895 (TOL5.069.920).

Sentencia de 10 de octubre de 1960 (TOL4.339.290).

Sentencia de 5 de abril de 1966 (RJ 1966, 1684).

Sentencia de 31 de diciembre de 1979 (RJ 1979, 4499).

Sentencia de 8 de abril de 1982 (RJ 1982, 1941).

Sentencia de 10 de febrero de 1986 (RJ 1986, 513).

Sentencia de 10 de marzo de 1987 (RJ 1987, 1425).

Sentencia de 5 de noviembre de 1987 (RJ 1987, 8336).

Sentencia de 10 de noviembre de 1987 (RJ 1987, 8367).

Sentencia de 26 de septiembre de 1989 (RJ 1989, 6381).

Sentencia de 13 de febrero de 1990 (RJ 1990, 684).

Sentencia de 26 de diciembre de 1990 (RJ 1990, 10370).

Sentencia de 23 de mayo de 1991 (RJ 1991, 3786).

Sentencia de 8 de noviembre de 1991 (RJ 1995, 6633).

Sentencia de 28 de noviembre de 1992 (RJ 1992, 9449).

Sentencia de 17 de marzo de 1995 (RJ 1995, 1961).

Sentencia de 28 de julio de 1995 (RJ 1995, 6633).

Sentencia de 24 de diciembre de 1996 (RJ 1996, 9506).

Sentencia de 19 de mayo de 1997 (RJ 1997, 4113).

Sentencia de 6 de noviembre de 1998 (RJ 1998, 8166).

Sentencia de 22 de marzo de 2000 (RJ 2000, 2485).

Sentencia de 5 de febrero de 2002 (RJ 2002, 1600).

Sentencia de 7 de noviembre de 2002 (RJ 2002, 9484).

Sentencia de 17 de enero de 2003 (RJ 2003, 433).

Sentencia de 5 de noviembre de 2003 (RJ 2003, 8026).

Sentencia de 7 de julio de 2004 (RJ 2004, 5105).

Sentencia de 9 de julio de 2004 (RJ 2004, 5246).

Sentencia de 17 de marzo de 2005 (RJ 2005, 2389).

Sentencia de 31 de julio de 2007 (RJ 2007, 6258).

Sentencia de 8 de octubre de 2010 (RJ 2010, 8009).

Sentencia de 1 de marzo de 2013 (RJ 2013, 7414).

Sentencia de 29 de abril de 2015 (RJ 2015, 1918).

Sentencia de 1 de junio de 2016 (RJ 2016, 2319).

\section{Sala Tercera}

Sentencia de 22 de junio de 1994 (RJ 1994, 5092).

Sentencia de 18 de marzo de 1995 (RJ 1995, 2500). 
Sentencia de 5 de febrero de 1996 (RJ 1996, 1039).

Sentencia de 15 de abril de 1997 (RJ 1997, 3086).

Sentencia de 26 de febrero de 1999 (RJ 1999, 1823).

Sentencia de 17 de mayo de 1999 (RJ 1999, 3988).

\section{Sala Cuarta}

Sentencia de 9 de junio de 2008 (RJ 2008, 4226).

Sentencia de 24 de septiembre de 2008 (RJ 2008, 5658).

Sentencia de 28 de junio de 2013 (RJ 2013, 6241).

\section{Tribunales Superiores de Justicia}

Sentencia del TSJ de Cataluña (Sala de lo Civil y Penal) de 22 de enero de 2004 (RJ 2004, 1037).

Auto del TSJ de Cataluña (Sala de lo Civil y Penal) de 14 de octubre de 2013 (RJ 2014, 147).

Sentencia del TSJ de Cataluña (Sala de lo Social) de 12 de enero de 2018 (AS 2018, 949).

\section{Audiencias provinciales y Audiencia Territorial}

Sentencia de la Audiencia Provincial de Lugo de 27 de abril de $1994^{57}$

Sentencia de la Audiencia Provincial de Las Palmas (Sección 5.a) de 11 de mayo de 2000 (JUR 2009, 100818).

Sentencia de la Audiencia Provincial de Albacete (Sección 2.a) de 15 de octubre de 2001 (JUR 2014, 191950).

Sentencia de la Audiencia Provincial de Burgos (Sección 2. ${ }^{\mathrm{a}}$ ) de 11 de diciembre de 2006 (AC 2007, 1050).

Sentencia de la Audiencia Provincial Barcelona (Sección 4. ${ }^{\mathrm{a}}$ ) de 28 de octubre de 2008 (JUR 2009, 64243).

Sentencia de la Audiencia Provincial de Barcelona (Sección 1. a) de 7 de mayo de 2013 (JUR 2013, 218041).

Sentencia de la Audiencia Provincial de Albacete (Sección 2. ${ }^{\text {a) }}$ de 10 de junio de 2014 (JUR 2014, 191950).

\section{Dirección General de los Registros y del Notariado}

Resolución de 20 de julio de 2016 (RJ 2016, 4595).

57 Pro manuscrito, amablemente remitida por la Audiencia Provincial de Lugo a instancia de parte (no consta la sección de procedencia). 